\title{
MEMBANGUN SISTEM INFORMASI SEKOLAH BERBASIS WEB PADA SMA NEGERI 4 RAHA
}

\author{
Yenni Darna Koes Indah, Firdaus, Rahmawati, Darman \\ Email: darman@umkendari.ac.id
}

\begin{abstract}
ABSTRAK
Penelitian ini bertujuan Mendesain Sistem Informasi Sekolah Berbasis Web dengan menggunakan bahasa pemrograman PHP dan mengukur tingkat kelayakan Sistem Informasi berbasis web yang dirancang. Metode yang digunakan dalam penelitian ini adalah metode penelitian pengembangan (Developmen Research), dengan pendekatan deskriptif. Penelitian ini dilaksanakan pada SMA Negeri 4 Raha mulai bulan Juli sampai Bulan September 2015. Objek penelitian ini berupa Sistem Informasi Sekolah Berbasis Web SMA Negeri 4 Raha. Pengumpulan data dilakukan dengan observasi, dokumentasi dan instrumen. Teknik analisis data dilakukan dengan teknik analisis deskriptif.

Hasil penelitian ini adalah Sistem Informasi Sekolah Berbasis Web SMA Negeri 4 Raha. Sistem Informasi Sekolah Berbasis Web SMA Negeri 4 Raha dinyatakan layak berdasarkan hasil uji kelayakan oleh ahli SIM dengan persentase total sebesar 79,76 \%, Uji Kelayakan oleh Pihak Sekolah dengan persentase total sebesar 62,86 \%, Hasil Uji Kelayakan oleh User dengan persentase total sebesar 94,94\% . Dengan Persentase Keseluruhan Hasil Uji Coba dengan persentase 75,90 \%. Dari hasil uji kelayakan di atas dapat disimpulkan Sistem Informasi Sekolah Berbasis Web SMA Negeri 4 Raha yang didesain layak digunakan sebagai media informasi SMA Negeri 4 Raha.
\end{abstract}

Kata Kunci: Sistem Informasi Sekolah, Web.

\section{Pendahuluan}

\section{Latar Belakang}

Perkembangan teknologi informasi saat ini berkembang cukup pesat. Hampir semua instansi pemerintah dalam berbagai bidang menggunakan atau memakai teknologi informasi khususnya internet untuk sekedar membuat informasi atau iklan yang diharapkan mampu mengenalkan instansi mereka ke masyarakat luas. Tidak terkecuali untuk instansi pemerintah yaitu sekolah negeri yang berada dibawah Departemen Pendidikan dan Kebudayaan.

Sekolah negeri di kota-kota besar saat ini banyak dikenal masayarakat luas karena salah satunya yaitu adanya informasi yang bisa dijangkau masyarakat di kota maupun daerah. Mereka sudah sejak lama menggunakan internet untuk mengenalkan dan mendekatkan sekolah mereka ke masyarakat, seperti membuat iklan, bahkan sistem informasi berbasis web yang bisa menjadi kebanggaan tersendiri bagi sekolah maupun siswa (i) sekolah tersebut.

Web adalah sebuah penyebaran informasi melalui internet. Sebenarnya antara www (world wide web) dan web adalah sama karena kebanyakan orang menyingkat www menjadi web saja. Web merupakan hal yang tidak dapat dipisahkan dari dunia internet. Melalui web, setiap pemakai internet bisa mengakses informasi-informasi di situs web yang tidak hanya berupa teks, tetapi juga dapat berupa gambar, suara, film, animasi, dan informasi lainnya.

SMA Negeri 4 Raha merupakan Salah satu sekolah negeri yang berada di kota raha, Selama ini untuk menyampaikan informasi kepada siswa dan stekholder hanya berupa menempelkan pengumuman di papan pengumuman sekolah maupun di spanduk-spanduk. Namun hal semacam ini sangat terbatas dan hanya yang datang disekolah saja yang dapat melihat informasi tersebut. Untuk mengatasi hal tersebut diperlukan suatu terobosan baru untuk menyebarluaskan informasi kepada stekholder, berupa sistem informasi sekolah berbasis web. 
Dengan sistem informasi ini semua informasi sekolah dapat diakses oleh masyarakat baik di kota maupun di daerah bahkan di dunia yang terhubung dengan internet. Dengan adanya sistem informasi ini akan mendekatkan sekolah kepada masyarakat, sebenarnya sekolah tersebut telah mempromosikan sekolahan mereka kepada masyarakat khususnya bagi siswa yang ingin melanjutkan kesekolah yang lebih tinggi. Dengan demikian, siswa yang mempunyai prestasi tertentu dalam bidang akademik maupun non akademik dapat mengetahui sekolah mana yang memang layak untuk tempat sekolah mereka nantinya, tanpa menunggu promosi melalui spanduk maupun datang ke sekolah-sekolah.

Oleh karena itu, berdasarkan hal tersebut diatas maka akan dirancang "Sistem Informasi Sekolah Berbasis Web" yang akan digunakan untuk mengenalkan dan mendekatkan sekolah ke masyarakat. Dengan sistem informasi berbasis web tersebut masyarakat dapat mengetahui mulai dari sejarah sekolah, kepala sekolah, profil sekolah, Fasilitas Sekolah bahkan program unggulan atau prestasi-prestasi yang pernah dicapai oleh SMA Negeri 4 Raha. Dengan dibuatnya sistem informasi berbasis web tersebut diharapkan mampu melecut semangat belajar dan bisa lebih berprestasi bagi siswa siswinya dan menjadi cambuk bagi SMA Negeri 4 Raha untuk meningkatkan kualitas serta kuantitas dalam bidang akademik maupun non akademik, karena dengan keberadaan sistem informasi berbasis web ini hampir semua informasi dapat diketahui masyarakat luas.

\section{Rumusan masalah}

Berdasarkan latar belakang di atas, maka dapat diangkat suatu permasalahan Bagaimana membangun Sistem Informasi Sekolah Berbasis Web dengan menggunakan bahasa pemrograman PHP agar informasi dari SMA Negeri 4 Raha dapat diakses secara luas?

\section{Tujuan Penelitian}

Berdasarkan rumusan masalah di atas, maka yang menjadi tujuan dari penelitian ini adalah Mendesain Sistem Informasi Sekolah Berbasis Web dengan menggunakan bahasa pemrograman PHP dan mengukur tingkat kelayakan Sistem Informasi berbasis web yang dirancang.

\section{Manfaat Penelitian}

Manfaat dari penelitian ini adalah:

1. Sebagai sarana untuk menyebarluaskan informasi SMA Negeri 4 Raha.

2. Untuk memperkenalakan SMA Negeri 4 Raha kepada masyarakat luas.

3. Sebagai bahan rujukan untuk mengembangkan Sistem informasi yang komplek SMA Negeri 4 Raha.

\section{LANDASAN TEORI}

\section{Konsep Dasar Sistem Informasi berbasis Web}

\section{Pengertian Sistem}

Suatu sistem sangatlah dibutuhkan dalam suatu perusahaan atau instansi pemerintahan, karena sistem sangatlah menunjang terhadap kinerja perusahaan atau instansi pemerintah, baik yang berskala kecil maupun besar. Supaya dapat berjalan dengan baik diperlukan kerjasama diantara unsur-unsur yang terkait dalam sistem tersebut.

Sistem adalah suatu jaringan kerja dari prosedur-prosedur yang saling berhubungan, berkumpul bersama-sama untuk melakukan suatu kegiatan atau untuk menyelesaikan suatu sasaran tertentu. (Jogiyanto, 2005).

Istilah sistem secara umum dapat didefinisikan sebagai kumpulan hal atau elemen yang saling bekerja sama atau yang dihubungkan dengan cara-cara tertentu sehingga membentuk satu kesatuan untuk melaksanakan suatu fungsi guna mencapai suatu tujuan. Sistem mempunyai karakteristik atau sifat - sifat tertentu, yaitu : Komponen Sistem, Batasan Sistem, Lingkungan Luar Sistem, Penghubung Sistem, Masukan Sistem, Keluaran Sistem, Pengolahan Sistem danSasaran Sistem (Sutanta. Edhy, 2009) 


\section{Pengertian Informasi}

Informasi adalah data yang diolah menjadi bentuk yang lebih berguna dan lebih berarti bagi yang menerimanya.Sumber dari informasi adalah data. Data merupakan bentuk jamak dari bentuk tunggal datum atau data item. Data adalah kenyataan yang menggambarkan suatu kejadian-kejadian dan kesatuan nyata. (Jogiyanto, 2005).

Informasi adalah data yang diolah menjadi bentuk yang berguna dan menjadi berarti bagi penerimanya. Kegunaan informasi adalah untuk mengurangi ketidakpastian di dalam proses pengambilan keputusan tental 5 」 keadaan. Suatu informasi dikatakan bernilai bila manfaatnya lebih efektif diband 5 dengan biaya untuk mendapatkan informasi tersebut. Kualitas informasi sangat aıpengaruhi atau ditentukan oleh beberapa hal yaitu : Relevan (Relevancy), Akurat (Accurancy), Tepat waktu (Time liness), Ekonomis (Economy), Efisien (Efficiency), Ketersediaan (Availability), Dapat dipercaya (Reliability), Konsisten (Sutanta. Edhy, 2009 )

\section{Pengertian Sistem Informasi}

Sistem informasi menurut Robert A. Leitch dan K. Roscoe Davis (Jogiyanto, 2005) adalah suatu sistem di dalam suatu organisasi yang mempertemukan kebutuhan pengolahan transaksi harian, mendukung operasi, bersifat manajerial dan kegiatan strategi dari suatu organisasi dan menyediakan pihak luar tertentu dengan laporan-laporan yang diperlukan.

Sistem informasi merupakan suatu perkumpulan data yang terorganisasi beserta tatacara penggunaanya yang mencangkup lebih jauh dari pada sekedar penyajian. Istilah tersebut menyir atkan suatu maksud yang ingin dicapai dengan jalan memilih dan mengatur data serta menyusun tatacara penggunaanya. Keberhasilan suatu sistem informasi yang diukur berdasarkan maksud pembuatanya tergantung pada tiga faktor utama, yaitu : keserasian dan mutu data, pengorganisasian data, dan tatacara penggunaanya.untuk memenuhi permintaan penggunaan tertentu, maka struktur dan cara kerja sistem informasi berbeda-beda ber gantung pada macam keperluan atau macam permintaan yang harus dipenuhi. Suatu persamaan yang menonjol ialah suatu sistem informasi menggabungkan berbagai ragam data yang dikumpulkan dari berbagai sumber. Untuk dapat menggabungkan data yang berasal dari berbagai sumber suatu sistem alih rupa (transformation) data sehingga jadi tergabungkan (compatible). Berapa pun ukurannya dan apapun ruang lingkupnya suatu sistem informasi perlu memiliki ketergabungan (compatibility) data yang disimpannya. (Al Fatta. Hanif, 2007)

Menurut Sutabri (2005), sistem informasi adalah suatu sistem di dalam suatu organisasi yang mempertemukan kebutuhan pengolahan transaksi harian yang mendukung fungsi operasi organisasi yang bersifat manajerial dengan kegiatan strategi dari suatu organisasi untuk dapat menyediakan kepada pihak luar tertentu dengan laporan-laporan yang diperlukan.

Berdasarkan pendapat-pendapat di atas dapat disimpulkan bahwa sistem informasi adalah sekumpulan prosedur organisasi yang dilaksanakan untuk mencapai suatu tujuan yaitu memberikan informasi bagi pengambil keputusan dan untuk mengendalikan organisasi.

Informasi dalam lingkup sistem informasi memiliki beberapa ciri yaitu:

a. Baru, informasi yang didapat sama sekali baru dan segar bagi penerima.

b. Tambahan, informasi dapat memperbaharui atau memberikan tambahan pada informasi yang telah ada.

c. Korektif, informasi dapat menjadi suatu koreksi atas informasi yang salah sebelumnya.

d. Penegas, informasi dapat mempertegas informasi yang telah ada.

\section{Bahasa Pemrograman}

1. PHP

Perl Hypertext Preprocessor (php) merupakan bahasa scripting dan interpreter yang digunakan dalam pemrograman web. PHP merupakan bahasa yang disertakan dalam dokumen HTML bekerja di sisi server sehingga script-nya tak tampak di sisi client. PHP dirancang untuk dapat bekerja sama dengan database server dan dibuat sedemikian rupa sehingga pembuatan dokumen HTML yang dapat mengakses database menjadi lebih mudah. 
PHP diperkenalkan pertama kali oleh Rasmus Lerdorf di akhir 1994. Ketersediaan source code dalam bahasa C membuat PHP sangat universal dan mudah disesuaikan dengan platform yang kita gunakan, sehingga tidak PHPu keraguan untuk menginvestasikan waktu dan tenaga guna mengembangkan aplikasi PHP. PHP juga modular, kemampuannya dalam mengenal berbagai database server tidak terpasang seluruhnya. Hal ini penting guna efisiensi dan penghematan memori. Jadi misalkan database yang kita gunakan adalah MySQL maka kita tidak PHPu meng-compile PHP untuk mendukung database yang lain. PHP bekerja di sisi server (menyatu dengan web server), PHP juga dapat mengakses database server yang berada di remote host. Tentu saja hal ini PHPu didukung oleh database server itu sendiri, karena tidak semua database server menyediakan fasilitas remote access. Selama masa pembuatan, browser, web server dan database server dapat menyatu dalam sebuah host, jadi tidak harus online untuk mencoba aplikasi yang dibuat dengan PHP. (Medinets, 2000).

Untuk menjalankan PHP dibutuhkan web server. Web server berfungsi menyimpan serta mendistribusikan data ke komputer lain lewat internet yang meminta informasi tersebut. Apache merupakan web server yang dikeluarkan oleh NSCA yaitu NSCA HTTPD sekitar tahun 1995. (Imansyah, 2003).

2. Database

Database adalah kumpulan file-file yang saling berelasi, relasi tersebut biasa ditunjukkan dengan kunci dari tiap file yang ada. Satu database menunjukkan satu kumpulan data yang dipakai dalam satu lingkup perusahaan atau instansi. Dalam satu file terdapat record-record yang sejenis, sama besar, sama bentuk, merupakan satu kumpulan entity yang seragam. Satu record terdiri dari field- field yang saling berhubungan untuk menunjukkan bahwa field tersebut dalam satu pengertian yang lengkap dan direkam dalam satu record (Kristanto, 2004).

3. $M y S q l$

MySQL (Structured Query Language) merupakan sebuah server database yang banyak digunakan di internet karena kehandalannya, keamanan dan juga sifat yang freeware. MySQL mendukung terhadap pemrograman C, PHP, Java, PHP dan Phyton. MySQL juga mendukung terhadap sistem operasi berbasis Unix, Windows dan OS/2. MySQL adalah mesin basis data yang sama ketika proses-proses pada aplikasi itu berjalan secara simultan. Program utilitas MySQL dapat menggunakan pernyataan SQL. (Medinets, 2000)

\section{Aplikasi Pendukung}

1. XAMPP

XAMPP adalah perangkat lunak bebas, yang mendukung banyak sistem operasi, merupakan kompilasi dari beberapa program. Fungsinya adalah sebagai server yang berdiri sendiri (localhost), yang terdiri atas program Apache HTTP Server, MySQLdatabase, dan penerjemah bahasa yang itulis dengan bahasa pemrograman PHP dan Perl. Nama XAMPP merupakan singkatan dari $\mathrm{X}$ (empat sistem operasi apapun), Apache, MySQL, PHP dan Perl. Program ini tersedia dalam GNU General Public License dan bebas, merupakan web server yang mudah digunakan yang dapat melayani tampilan halaman web yang dinamis.

2. Notepad ++

Notepad++ adalah sebuah penyunting teks dan penyunting kode sumber yang berjalan di sistem operasi Windows. Notepad++ menggunakan komponen Scintilla untuk dapat menampilkan dan menyuntingan teks dan berkas kode sumberberbagai bahasa pemrograman.

Notepad ++ didistribusikan sebagai perangkat lunak bebas. Proyek ini dilayani oleh Sourceforge.net dengan telah diunduh lebih dari 27 juta kali dan dua kali memenangkan penghargaan SourceForge Community Choice Award for Best Developer Tool.

3. Webroswer

Penjelajah web atau peramban web adalah perangkat lunak yang berfungsi untuk menerima dan menyajikan sumber informasi di Internet. Sebuah sumber informasi diidentifikasi dengan pengidentifikasi sumber seragam yang dapat berupa halaman web, gambar, video, atau jenis konten lainnya. 
Meskipun penjelajah web terutama ditujukan untuk mengakses Internet, sebuah penjelajah juga dapat digunakan untuk mengakses informasi yang disediakan oleh server web dalam jaringan pribadi atau berkas pada sistem berkas. Beberapa penjelajah web yang populer adalah Google Chrome, Firefox, Internet Explorer, Opera, dan Safari.

\section{Deskripsi Umum Sistem Informasi Sekolah SMA Negeri 4 Raha}

SMA Negeri 4 Raha merupakan salah satu sekolah negeri yang ada di kabupaten muna, Sekolah ini berlokasi di kecamatan Motewe kabupaten Muna. Sekolah ini didirikan pada tahun 2002 silam dengan nama SMAN Khusus, yang pada awal pendiriannya bertujuan untuk menjadi SMA unggulan di kabupaten Muna, dimana siswa dan tenaga pendidiknya merupakan yang terbaik hasil seleksi dasi sekolah-sekolah negeri yang ada dikabupaten muna.

Sistem Informasi Sekolah (website) SMA Negeri 4 Raha merupakan suatu wadah untuk menyebarluaskan informasi sekolah kepada masyarakat berupa :

1. Sejarah berdirinya SMA Negeri 4 Raha

Dilandasi oleh keinginanan yang kuat oleh pemerintah Daerah kabupaten muna yang menginginkan adanya SMA Negeri unggulan di daerah, maka pemerintah daerah dalam hal ini Dinas Pendidikan kabupaten Muna Tahun 2001 mulai merancang berdirinya SMA Khusus dengan mulai mengadakan seleksi calon guru untuk di tempatkan di SMAN tersebut. yang berasal dari Guru-guru seluruh SMAN yang ada di kabupaten Muna. Ditahun yang sama diangkatlah kepala sekolah pertama Drs. Sentot Edy Purnomo dan beberapa guru hasil seleleksi yang di adakan oleh dinas pendidikan. Siring waktu berjalan pembahasan program sekolah menjadi khusus antara pemerintah dan DPR mengalami pasang surut hingga program ini untuk sementara di hentikan karena masalah pendanaan. Melalui mebijakan dinas pendidikan kabupaten akhirnya program SMAN Khusus di samakan dengan program SMAN lainnya seperti SMA-SMA lainnya di kabupaten Muna. Pada awal berdirinya tahun 2001/2002 SMAN Khusus menerima ssiswa sebanyak 3 kelas. dan pada tahun 2004/2005 untuk pertama kalinya menamatkan siswanya sebanyak 54 Orang,23 siswa jurusan IPA dan 31 siswa jurusan IPS. Hingga saat ini tahun ajaran 2014/2015 telah menamatkan siswanya sebanyak 603 Siswa. untuk sarana prasarana sejauh berdirinya pada tahun 2001 terdiri dari 6 lokal Asrama Siswa, 1 lokal Kantor, 1 lokal Lab IPA, 1 lokal Perpustakaan, 1 lokal gedung keterampilan, 6 lokal Ruang Belajar, 1 lokal Mushola dan 1 lokal Gudang. Tahun 2015 telah bertambah 1 ruang belajar 1 lokal Lab Kimia. tahun 2015 pula melalui surat keputusan Bupati Muna Nama Sekolah di ganti dari SMAN KHUSUS menjadi SMA Negri 4 Raha di bawah Pimpinan Kepalah Sekolah Ahmad Djaya Adi,S.Pd.Mm.

2. Profil Sekolah

\begin{tabular}{|l|l|}
\hline A.Identitas Sekolah & \\
\hline Nama Sekolah & $:$ SMAN KHUSUS RAHA \\
\hline NPSN NSS & $: 40403155 / 301200213008$ \\
\hline Jenjang Pendidikan & $:$ SMA \\
\hline Status sekolah & $:$ Negri \\
\hline B. Lokasi sekolah. & \\
\hline Alamat & $:$ Jl Sugi Patola \\
\hline RT/RW & $: 1 / 2$ \\
\hline Nama Dusun & $:$ Motewe \\
\hline Desa/Kelurahan & $:$ Lasalepa \\
\hline Kode Pos & $: 93654$ \\
\hline Kecamatan & $:$ Lasalepa \\
\hline Lintang/Bujur & $: 4787900 / 122.718500$ \\
\hline C. Data Pelengkap &
\end{tabular}


Sekolah.

SK Pendirian Sekolah : 1188

Tgl SK Pendirian : 20030909

Status Kepemilikan : Pemerintah Daerah

SK Izin Operasional : 188

3. Visi dan Misi

VISI

Menjadi kebanggaan masyarakat Kab. Muna karena lulusannya Beriman, Berpretasi Tinggi ,Sehat dan Berbudaya.

MISI

Misi SMAN 4 Raha 2011-2015 adalah:

a. Melaksanakan KBM secara efektif.

b. Melaksanakan Bimbingan dan Tambahan Pelajaran di luar jam Pelajaran.

c. Melaksanakan Kegiatan Ekstrakurikuler/ Pengembangan Diri

d. Meningkatkan Ketertiban dan Kedisiplinan.

e. Mengadakan kegiatan Keagamaan secara berkala.

f. Mewujudkan Lingkungan Sekolah yang Bersih, Indah, Asri dan Nyaman.

g. Mewujudkan Sekolah Standar Nasional (SSN) / Sekolah Standar Internasional (SSI)

4. Tenaga Pendidik dan Tenaga Kependidikan

a. Tenaga Pendidik

Tabel 2.1 Tenaga Pendidik

\begin{tabular}{|l|l|l|l|}
\hline \multicolumn{1}{|c|}{ NAMA } & \multicolumn{1}{|c|}{$\begin{array}{l}\text { PANGKAT/ } \\
\text { GOLONGAN }\end{array}$} & \multicolumn{1}{c|}{ JABATAN } & STATUS \\
\hline Haidir,S.Pd, M.Si & II/b & Tenaga Pendidik & PNS \\
\hline Ahmad Djaya Adi.S.Pd.Mm & IV/a & Kepala Sekolah & PNS \\
\hline $\begin{array}{l}\text { Muhammad Akhram } \\
\text { Larisu.S.Pd.M.Sc }\end{array}$ & IV/a & Tenaga Pendidik & PNS \\
\hline Muhammad Sidiq.,S.Pd.,M.Pd & IV/a & Tenaga Pendidik & PNS \\
\hline Pade Mustafa.,S.Pd.,M.Pd & IV/a & Tenaga Pendidik & PNS \\
\hline Nasni Nini.,S.Pd,M.Pd & IV/a & Tenaga Pendidik & PNS \\
\hline Muhammad Sidiq.,S.Pd.,M.Pd & IV/a & Tenaga Pendidik & PNS \\
\hline Drs. La Ode Onda & IV/a & Tenaga Pendidik & PNS \\
\hline Karimudin,S.Pd .M.Pd & IV/a & Tenaga Pendidik & PNS \\
\hline Halyadin ,S.Pd .M,Pd & IV/a & Tenaga Pendidik & PNS \\
\hline Wa Ode Saabe.,S.Pd.M.Pd & IV/a & Kepala Sekolah & PNS \\
\hline Waode Aksa.S.SoS & IV/a & Tenaga Pendidik & PNS \\
\hline
\end{tabular}

Sumber : SMA Negeri 4 Raha, 2015

b. Tenaga Kependidikan

Tabel 2.2 Tenaga Kependidikan

\begin{tabular}{|l|c|c|c|}
\hline \multicolumn{1}{|c|}{ NAMA } & $\begin{array}{c}\text { PANGKAT/ } \\
\text { GOLONGAN }\end{array}$ & JABATAN & STATUS \\
\hline Farida.S.Pd & II/a & $\begin{array}{c}\text { Tenaga } \\
\text { Administrasi }\end{array}$ & PNS \\
\hline Haidir,S.Pd,M,Si & II/b & $\begin{array}{c}\text { Tenaga } \\
\text { Administrasi }\end{array}$ & PNS \\
\hline
\end{tabular}

Sumber : SMA Negeri 4 Raha, 2015 
5. Statistik Siswa dan Alumni Setiap Tahun.

a. Statistik Siswa

Tabel 2.3 Statistik Siswa

\begin{tabular}{|c|c|c|c|}
\hline KELAS & LAKI-LAKI & PEREMPUAN & JUMLAH \\
\hline IX & 27 & 30 & 57 \\
\hline$X$ & 30 & 38 & 68 \\
\hline XI & 28 & 36 & 44 \\
\hline
\end{tabular}

Sumber: SMA Negeri 4 Raha, 2015

b. Statistik Alumni

Tabel 2.4 Statistik Alumni

\begin{tabular}{|c|c|c|c|}
\hline TAHUN & LAKI-LAKI & PEREMPUAN & JUMLAH \\
\hline $2011 / 2012$ & 25 & 29 & 54 \\
\hline
\end{tabular}

Sumber : SMA Negeri 4 Raha, 2015

6. Fasilitas

Tabel 2.5 Fasilitas

\begin{tabular}{|c|c|c|c|c|}
\hline KODE & NAMA FASILITAS & JUMLAH & BAIK & RUSAK \\
\hline G-01 & Gudang & 2 unit & 2 unit & 0 unit \\
\hline G-02 & Laboratorium & 5 unit & 5 unit & 0 unit \\
\hline G-03 & Ruang Belajar & 8 unit & 8 unit & 0 unit \\
\hline G-04 & Perpustakaan & 1 unit & 1 unit & 0 unit \\
\hline G-05 & Ruang TU & 1 unit & 1 unit & 1 unit \\
\hline G-06 & Asrama Siswa & 6 unit & 6 unit & 0 unit \\
\hline G-06 & $\begin{array}{c}\text { Ruang Kepala } \\
\text { Sekolah }\end{array}$ & 1 unit & 1 unit & 0 unit \\
\hline
\end{tabular}

Sumber : SMA Negeri 4 Raha, 2015

7. Download

Download berisi tempat file-file yang dapat didownload berupa RPP, Silabus, Materi Ajar.

8. Galeri

Galeri berisi Dokumentasi Kegiatan SMA Negeri 4 Raha.

III. METODE PENELITIAN

Tempat dan Waktu Penelitian

Penelitian ini telah dilaksanakan pada bulan Juli sampai September 2015

bertempat di SMA Negeri 4 Raha, Kabupaten Muna.

\section{Jenis Penelitian}

Metode penelitian ini menggunakan penelitian pengembangan (Development

Research). Menurut Sugiyono (2010) Secara umum penelitian pengembangan (Development Research) terdiri dari 3 tahap yaitu :

1. Tahap Pertama adalah Studi Pendahuluan dilakukan dengan pendekatan deskriptif kualitatif, dimulai dengan studi literatur dan Studi lapangan.

2. Tahap Kedua adalah Tahap Desain Sistem Informasi dengan menggunakan bahasa pemrograman PHP.

3. Tahap Ketiga adalah Tahap Evaluasi atau Uji Kelayakan dengan pendekatan deskriptif kualitatif, Pada tahap ini, Uji Kelayakan dilakukan ditinjau dari aspek Kelayakan Konten (Isi) dan Kelayakan Desain.

\section{Prosedur Penelitian}

Prosedur penelitian membangun sistem informasi berbasis web (website) yang digunakan diaptasi dari model pengembangan yang dikembangkan oleh sugiono, 2010 yaitu sebagai berikut : 
1. Studi Pendahuluan

a. Studi literatur

Pada studi literatur dilakukan mengumpulkan bahan-bahan yang berkaitan dengan penelitian, Profil Sekolah, Jumlah Siswa Setiap Tahun, Jumlah Guru dan Tenaga Kependidikan, Sarana dan Prasarana, Jumlah alumni yang diluluskan setiap tahun, dan data-data lain yang akan dijadikan sebagai informasi.

b. Studi Lapangan

Studi lapangan dilakukan dengan melakukan kunjungan lapangan yaitu dengan berkunjung di SMA Negeri 4 Raha. Dalam studi lapangan ini didapat belum ada sistem informasi yang digunakan sebagai sarana yang digunakan untuk menyampaikan informasi secara luas kemasyarakat. Sarana yang digunakan dalam menyebar informasi adalah dengan membuat pengumuman dan menempelkan di papan pengumuman sekolah, serta memasang spanduk di sekitaran sekolah.

2. Desain Sistem Informasi (Website)

a. Merancang Database

Sebelum merancang tampilan website terlebih dahulu membuat database setelah itu membuat table-tabel dalam database seperti dibawah ini.

Tabel. 3.1. Tabel admin

\begin{tabular}{|c|c|c|}
\hline Nama Field & Type Data & Ukuran \\
\hline id & Int & 6 \\
\hline Username & varchar & 30 \\
\hline Password & varchar & 50 \\
\hline
\end{tabular}

Tabel 3.2. Tabel Agenda

\begin{tabular}{|c|c|c|}
\hline Nama Field & Type Data & Ukuran \\
\hline id & int & 6 \\
\hline tanggal & date & \\
\hline judul & varchar & 50 \\
\hline isi & text & \\
\hline pengirim & varchar & 50 \\
\hline
\end{tabular}

Tabel 3.3. Tabel Alumni

\begin{tabular}{|c|c|c|}
\hline Nama Field & Type Data & Ukuran \\
\hline id & int & 5 \\
\hline tahun & varchar & 10 \\
\hline laki-laki & varchar & 10 \\
\hline perempuan & varchar & 10 \\
\hline jumlah & varchar & 15 \\
\hline
\end{tabular}

Tabel 3.4. Tabel Berita

\begin{tabular}{|c|c|c|}
\hline Nama Field & Type Data & Ukuran \\
\hline id & int & 6 \\
\hline tanggal & datetime & \\
\hline judul & varchar & 50 \\
\hline head & varchar & 250 \\
\hline isi & text & \\
\hline pengirim & vachar & 30 \\
\hline
\end{tabular}

Tabel 3.5. Tabel Download 


\begin{tabular}{|c|c|c|}
\hline Nama Field & Type Data & Ukuran \\
\hline id & int & 11 \\
\hline nama & varchar & 200 \\
\hline ukuran & varchar & 200 \\
\hline tipe & varchar & 100 \\
\hline
\end{tabular}

Tabel 3.6. Tabel Fasilitas

\begin{tabular}{|c|c|c|}
\hline Nama Field & Type Data & Ukuran \\
\hline id & int & 10 \\
\hline kode & varchar & 20 \\
\hline nama & varchar & 200 \\
\hline jumlah & int & 6 \\
\hline baik & int & 4 \\
\hline rusak & int & 4 \\
\hline
\end{tabular}

Tabel 3.7. Tabel Galeri

\begin{tabular}{|c|c|c|}
\hline Nama Field & Type Data & Ukuran \\
\hline id & int & 10 \\
\hline judul & varchar & 200 \\
\hline nama & int & 200 \\
\hline
\end{tabular}

Tabel 3.8. Tabel Pegawai

\begin{tabular}{|c|c|c|}
\hline Nama Field & Type Data & Ukuran \\
\hline id & int & 10 \\
\hline nama & varchar & 75 \\
\hline pangkat & varchar & 20 \\
\hline jabatan & varchar & 50 \\
\hline status & varchar & 50 \\
\hline
\end{tabular}

Tabel 3.9. Tabel Pengumuman

\begin{tabular}{|c|c|c|}
\hline Nama Field & Type Data & Ukuran \\
\hline id & int & 6 \\
\hline tanggal & datetime & \\
\hline judul & varchar & 50 \\
\hline isi & text & \\
\hline
\end{tabular}

Tabel 3.10. Tabel Fasilitas

\begin{tabular}{|c|c|c|}
\hline Nama Field & Type Data & Ukuran \\
\hline id & int & 3 \\
\hline Sejarah & varchar & 10000 \\
\hline Visimisi & varchar & 10000 \\
\hline
\end{tabular}

Tabel 3.11. Tabel Siswa

\begin{tabular}{|c|c|c|}
\hline Nama Field & Type Data & Ukuran \\
\hline id & int & 5 \\
\hline kelas & varchar & 20 \\
\hline laki-laki & varchar & 10 \\
\hline perempuan & varchar & 10 \\
\hline jumlah & varchar & 15 \\
\hline
\end{tabular}

b. Merancang Tampilan Antarmuka.

1) Membuat alur data dan aktivitas yang dilakukan oleh admin.

Proses/Alur Input data oleh Admin 


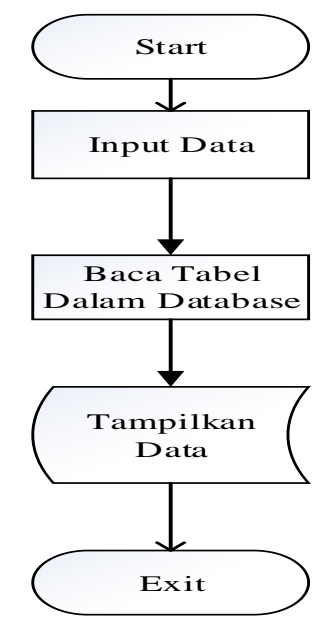

Gambar 3.1. Struktur/alur input data oleh admin

Pada gambar 3.1. di atas, data dapat dimasukkan pada satu database dengan table yang berbeda-beda sesuai dengan jenis data yang dimasukkan.

2) Membuat Diagram Alir

a) Diagram Alir Login Admin

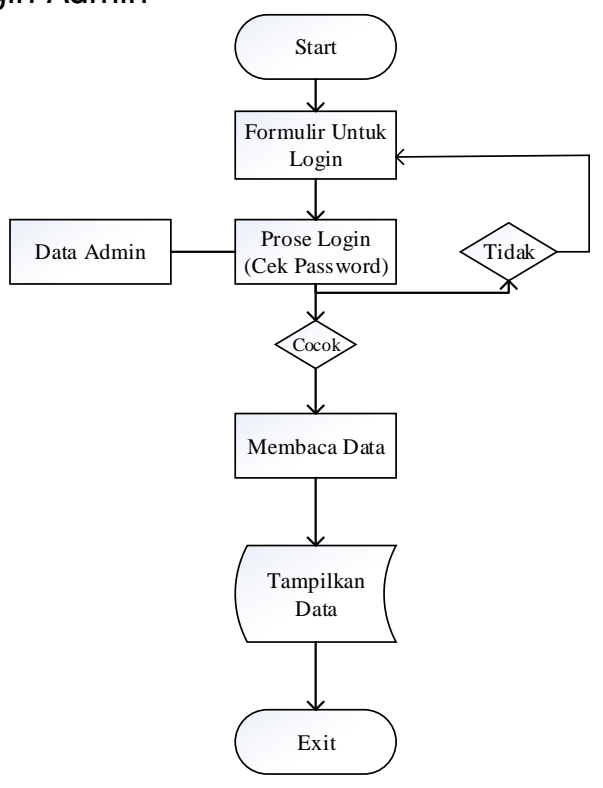

Gambar 3.2. Diagram Alir Login Admin

Pada Gambar 3.2. Admin login pada halaman login setelah itu data dicek apakah cocok dengan data yang ada pada table admin. Jika cocok maka akan lansung membaca data yang ada. Dan jika tidak maka kembali pada formulir login. 
b) Diagram Alir User

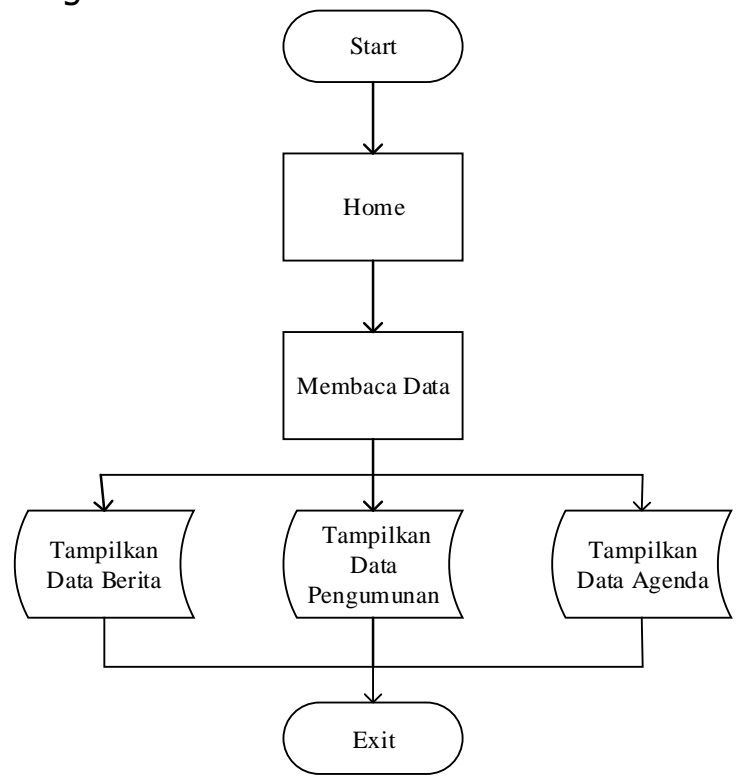

Gambar 3.3. Diagram Alir Aktifitas User

Pada gambar 3.3. User setelah masuk pada halaman berbada, dapat memilih data yang terdapat dalam website berupa data berita, data pengumuman dan data agenda.

c. Membuat Desain Interfaces

1) Desain interfaces menu home

Pada desain tampilan menu home ini, ada beberapa bahasa pemrogramanan yang digunakan yaitu : Html, PHP, CSS, Java Sript, dinama Html dan PHP digunakan untuk mendesain kerangka sedangkan CSS dan java scipt digunakan untuk mempercantik tampilan. Desain interfaces menu home ditunjukkan pada gambar 3.4.

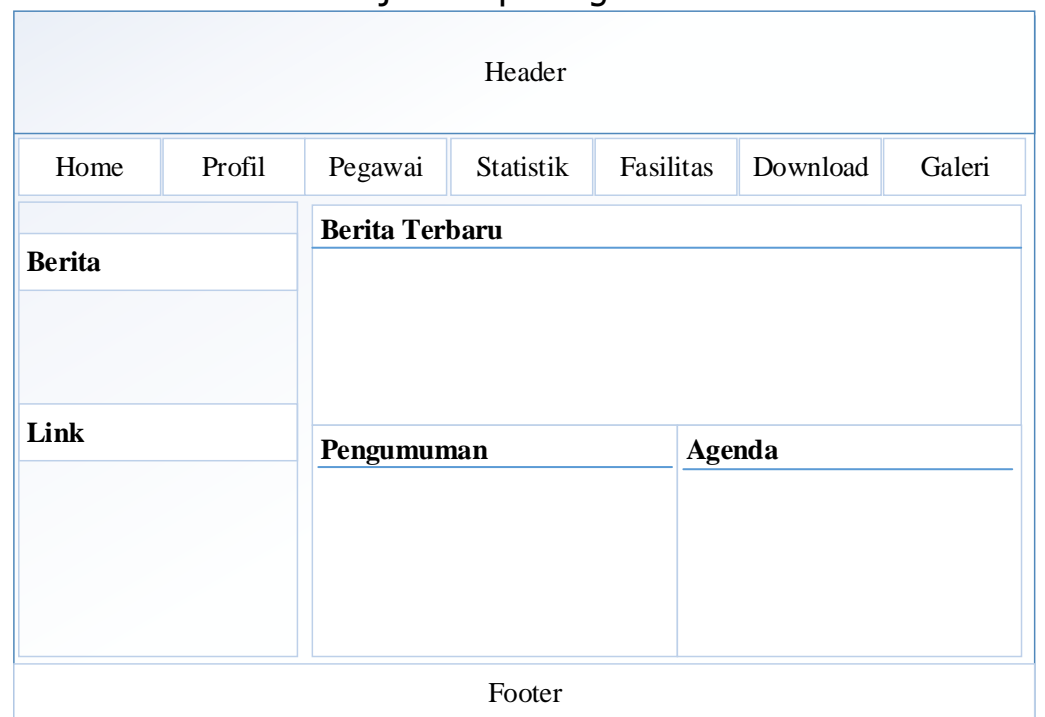

Gambar 3.4 Desain Interfaces menu Home 
2) Desain Interfaces Halaman Login

\begin{tabular}{|c|c|c|c|c|c|c|}
\hline \multicolumn{7}{|c|}{ Header } \\
\hline Home & Profil & Pegawai & Statistik & Fasilitas & Download & Galeri \\
\hline \multicolumn{7}{|c|}{ Username } \\
\hline \multicolumn{3}{|r|}{ Password } & & & & \\
\hline \multicolumn{7}{|c|}{ Footer } \\
\hline
\end{tabular}

3. Uji Kelayakan

Gambar 3.5 Desain Interfaces Halaman Login

Setelah dilakukan desain dan pengisian konten maka dilakukan uji kelayakan. Uji kelayakan bertujuan untuk mengetahui kelayakan system informasi (Website) yang telah didesai. Uji kelayakan ini dengan melibatkan 3 (tiga) Orang Ahli SIM, 5 (lima) Orang dari Pihak Seklah dan 10 (sepuluh) orang user.

4. Revisi.

Setelah dilakukan Uji Kelayakan, dalam penelitian ini ditemukan masih ada kekurangan dalam Hal Tampilan, Maka Validator menyarankan untuk melakukan perbaikan " Tambahkan variasi fitur terkait kegiatan sekolah", hal ini disarankan oleh Iksan, S.Kom.

5. Menghosting Website

Setelah selesai uji kelayakan Sistem Informasi (website), langkah selanjutnya adalah mengupload Sistem Informasi (website) kehosting yang telah dibeli. Tahap ini dinamakan proses pemindahan file-file dari komputer keserver penyedia layanan (hosting) sehingga nantinya bisa diakses oleh banyak orang di seluruh dunia. Setelah melakukan pembelian hosting maka file-file website dapat diupload pada server penyedia hosting, dengan terlebih dahulu login pada Cpanel. Halaman Login Cpanel dapat dilihat pada gambar 3.6. di bawah ini.

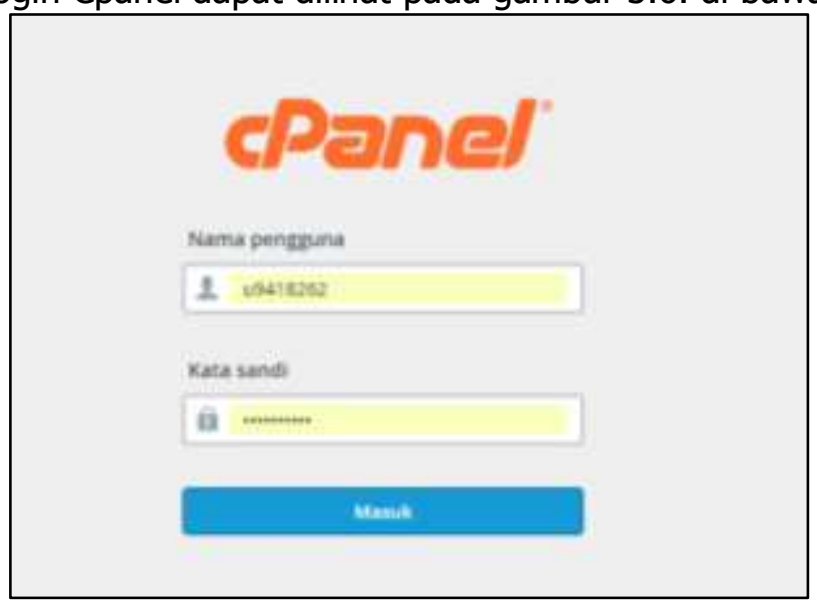

Gambar 3.6 Halaman Login Cpanel

Setelah melakukan login, maka lansung pada halaman utama Cpanel. Pada halaman ini terdaoat beberapa pilihan diantaranya filemanager, 
phpmyadmin. Halaman utama setelah login dapat dilihat pada gambar 3.7 di bawah ini.

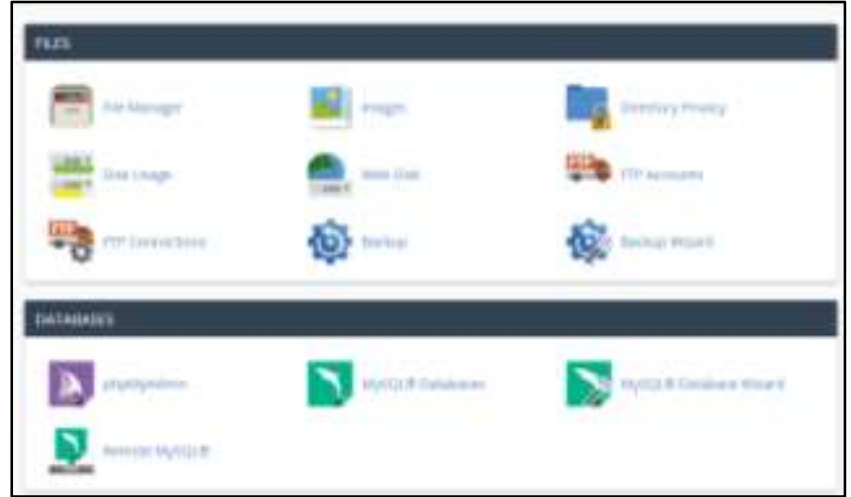

Gambar 3.7 Halaman Utama Cpanel

Setelah masuk pada halaman utam Cpanel, maka untuk mengupload file dapat dilakuakn dengan memasukan file-file pada file manager. Tampilan file manager dapat dilihat pada gambar 3.8.

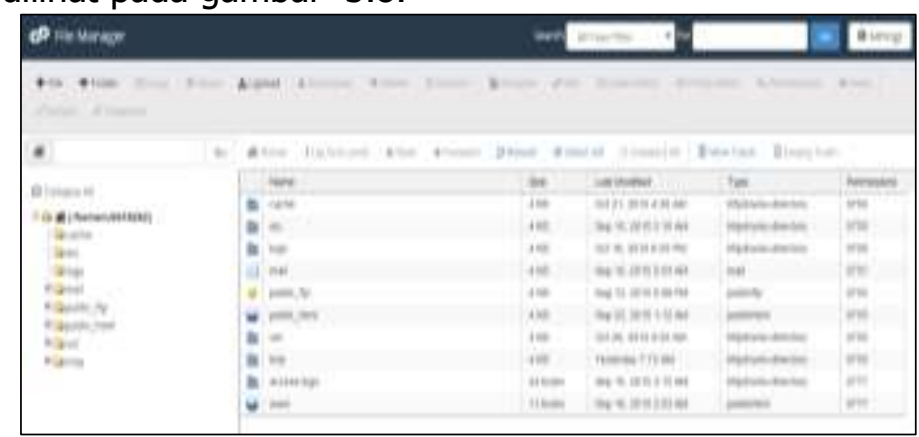

Gambar 3.8 Halaman File manager.

Setelah melakukan upload file-file maka selanjutnya melakukan inport database. Untuk melakukan itu maka, terlebih dahulu masuk pada menu Phpmyadmin. Halaman Phpmyadmin dapat dilihat pada gambar 3.9. dibawah ini.

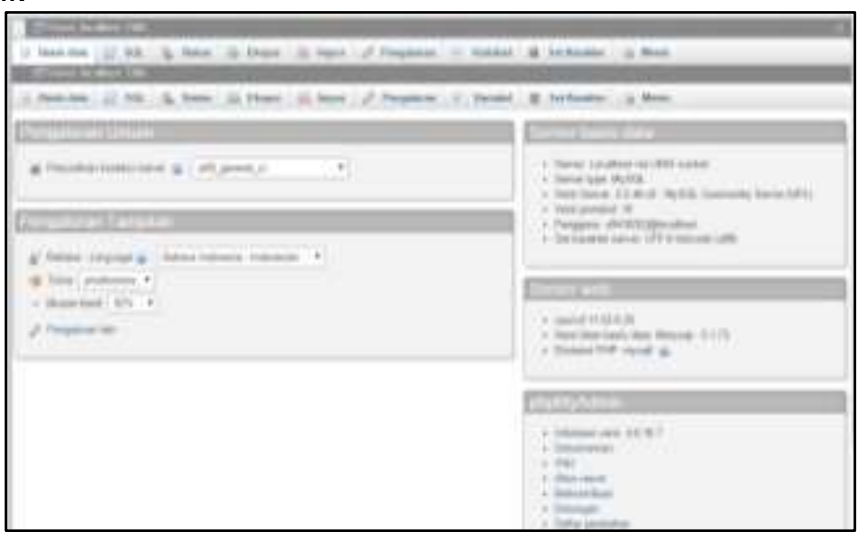

Gambar 3.9 Halaman Php Myadmin pada Cpanel.

Setelah dilakukan pengupload file-file dan database maka dalam waktu 24 jam website yang dihosting dapat diakses.

Demikian prosedur penelitian yang dilakukan dalam mendesain system informasi sekolah (website) SMA Negeri 4 Raha, Untuk lebih jelasnya dapat dilihat pada gambar 3.10. 


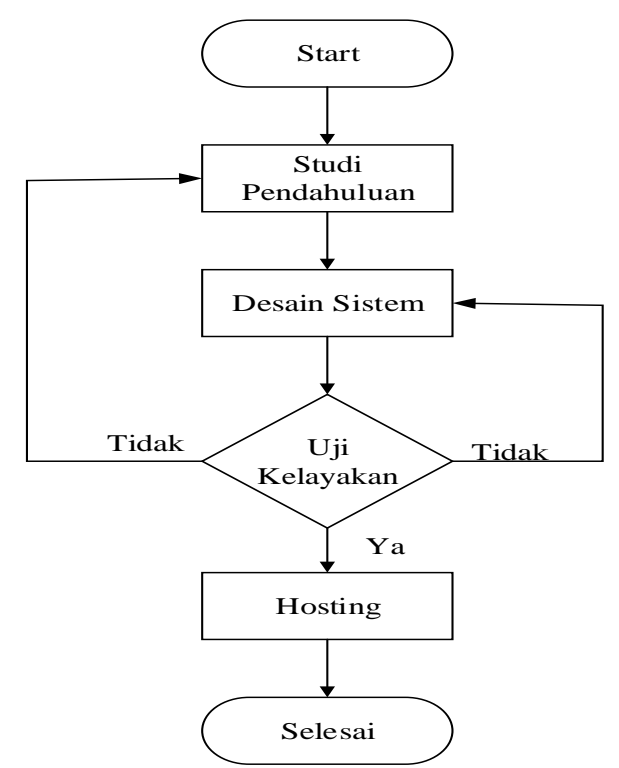

Gambar 3. 10. Flowchart Desain Sistem Informasi Sekolah Berbasis Web SMA Negeri 4 Raha

\section{Teknik Pengumpulan Data}

Teknik pengumpulan data merupakan langkah yang paling strategis dalam penelitian, karena tujuan utama dalam penelitian adalah mendapatkan data. Dalam penelititna ini teknik pengumpulan data yang dugunakan adalah :

1. Observasi

Observasi awal dengan melakukan kunjungan lapangan yaitu dengan berkunjung di SMA Negeri 4 Raha. Dalam observasi ini didapat belum ada sistem informasi yang digunakan sebagai sarana yang digunakan untuk menyampaikan informasi secara luas kemasyarakat. Sarana yang digunakan dalam menyebar informasi adalah dengan membuat pengumuman dan menempelkan di papan pengumuman sekolah, serta memasang spanduk di sekitaran sekolah.

2. Dokumentasi

Dokumentasi dilakukan dengan cara mengumpulkan bahan-bahan yang berkaitan dengan penelitian, Profil Sekolah, Jumlah Siswa Setiap Tahun, Jumlah Guru dan Tenaga Kependidikan, Sarana dan Prasarana, Jumlah alumni yang diluluskan setiap tahun, dan data-data lain yang akan dijadikan sebagai informasi.

3. Instrumen

Instrumen penelitian digunakan untuk memperoleh data dari uji kelayakan. Instrumen yang digunakan adalah instrumen evaluasi uji kelayakan digunakan untuk menilai kelayakan sistem informasi yang didesain yaitu dari aspek kelayakan desain sistem dan aspek Kelayakan konten (isi). Uji kelayakan ini dilakukan oleh Ahli SIM dan Pihak Sekolah, untuk ahli SIM sebanyak 3 Orang yaitu : 1) Iksan, S.Kom (Guru TIK dan Operator Dapodik SMA Negeri 1 Raha), 2) Haidir, S.Si,(Guru TIK dan Operator Dapodik SMA Negeri 4 Raha) dan Akmal Zuhri, S.Kom,(Staff Sekretaria Bapeda Raha) dan Pihak Sekolah (SMA Negeri 4 Raha) sebanyak 5 Orang yaitu : 1) La Sihani, S.Pd., M.Pd 2) Achmad Jaya Adi, S.Pd., MM, 3) La Unsa, S.Pd., M.Pd, 4) Muh. Akram La Risu, S.Pd., M.Sc dan 5) Muh. Sidiq, S.Pd., M.Pd, Serta Uji Coba Terhadap User dilakukan keapda Siswa/siswi sebanyak 10 orang.

\section{Teknik Analisis Data}

Data yang diperoleh melaui angket pada saat uji kelayakan selanjunya dianalisis dengan menggunakan statistik deskriptif kuantitatif. Penilaian dituangkan dalam distribusi skor dan persentase terhadap kategori skala yang telah ditentukan, setiap pertanyaan diberi bobot 1,2,3 dan 4 yang diuraikan sebagai berikut : 


\begin{tabular}{|c|c|}
\hline Interprestasi & Bobot \\
\hline Sangat Layak & 4 \\
\hline Layak & 3 \\
\hline Tidak Layak & 2 \\
\hline Sangat Tidak Layak & 1 \\
\hline
\end{tabular}

Data yang terkumpul diproses dengan cara dijumlahkan, dibandingkan dengan jumlah yang diharapkan dan diperoleh persentase (Arikunto, 1996), atau dapat ditulis dengan rumus sebagai berikut :

$$
P(s)=\frac{S}{n} x 100 \%
$$

Keterangan :

$\mathrm{P}(\mathrm{s}) \quad=$ Persentasi Kelayakan

$\mathrm{S} \quad=$ Skor yang diobservasi

$\mathrm{N} \quad=$ Skor yang diharapkan

Data yang terkumpul dianalisis dengan teknik analisis deskriptif kuantitatif yang diungkapkan dalam distribusi skor dan persentase terhadap kategori skala penilaian yang telah ditentukan. Setelah penyajian dalam bentuk persentase, langkah selanjutnya mendeskriptifkan dan mengambil kesimpulan tentang masing-masing indikator dapat menggunakan tabel berikut:

Tabel 3.13. Tabel skala persentase

\begin{tabular}{|c|c|}
\hline Persentase Pencapaia & Interprestasi \\
\hline $76-100 \%$ & Sangat Layak \\
\hline $56-75 \%$ & Layak \\
\hline $40-55 \%$ & Tidak Layak \\
\hline $0-39 \%$ & Sangat Tidak Layak \\
\hline
\end{tabular}

Sumber : Arikunto (1996)

\section{HASIL PENELITIAN}

\section{Desain Sistem Informasi Sekolah Berbasis Web}

Hasil dari penelitian ini adalah terciptanya system informasi sekolah berbasis web. Dalam website ini menampilkan informasi yang ada di sekolah berupa : Profil Sekolah, Guru dan Tenaga Kependidikan, Statistik Siswa dan Alumni, Fasilitas, Berita Pengumuman dan Agenda.

Sistem informasi Sekolah Berbasis Web SMA Negeri 4 Raha dibangun dengan menggunakan bahasa pemrograman PHP, HTMP dan Database MySql, Serta didukung oleh aplikasi pendukung seperti Xampp sebagai server dan Aplikasi Notepad ++ sebagai editor yang digunakan untuk mengedit Sript Program.

\section{Sistem Informasi Sekolah Berbasis Web}

a. Halaman Home

Halaman Home merupakan halaman utama yang pertama kali dibuka. Halaman utama ini berisi tentang Berita, Pengumuman dan Agenda. Pada bagian atas terdapat Menu Dropdown yang terdiri dari Profil Sekolah, Pegawai, Statistik, Fasilitas, Dowload, dan Galeri. Berikut ini Script Program untuk membuat menu dropdown :

$<$ nav class="art-nav clearfix" $>$

$<$ ul class="art-hmenu" $><$ ii $><a$ href="index.php" class="active" $>$ Home $</ a></ l i>$

$<$ li $><a$ href="\#" $>$ Profil $<\mid a><u l>$

$<$ li $><$ a href="sejarah.php" $>$ Sejarah $</ a></ l i>$

$<|i\rangle<a$ href="visimisi.php" $>$ Profil dan Visi Misi $</ a\rangle</|i\rangle\langle/$ ul $\rangle</|i\rangle$

$<\mid i><a$ href="\#" $>$ Pegawai $</ a><u l>$ 
$</ i><$ a href="tenagapendidik.php" $>$ Tenaga Pendidik $</ a\rangle</ / i>$

$<\mid i><a$ href="tenagaadministrasi.php" $>$ Tenaga Administrasi $</ a></|i\rangle</ u|></| i>$

$<$ ii $><$ a href="\#" $>$ Statistik $</ a><u l>$

$<$ li $><a$ href="siswa.php" $>$ Siswa $</ a></ l i>$

$<$ li $><a$ href="alumni.php" $>$ Alumni $</ a></ \mid i></ u l></ l i>$

$</ i><$ a href="fasilitas.php" $>$ Fasilitas $</ a></ l i>$

$<$ ii $><$ a href="download.php" $>$ Download $</ a></$ li $>$

$<\mid i><a$ href="galeri.php" $>$ Galeri $</ a></ \mid i></$ ul $>$

$</$ nav $>$.

Hasil dari listing program di atas adalah seperti pada gambar 4.1. dibawah ini:

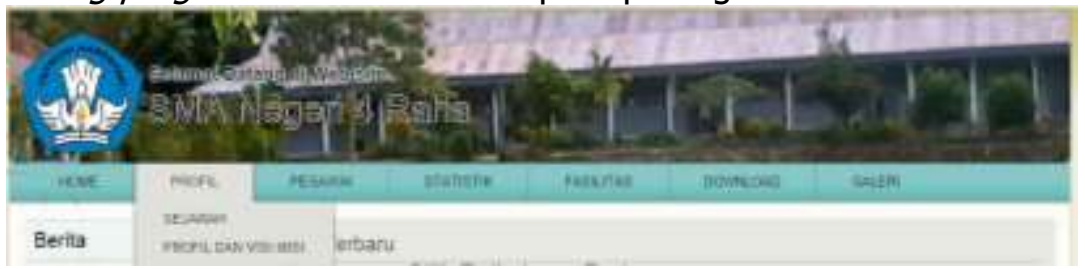

Gambar 4.1. Menu Dropdown

Dalam Sistem Informasi ini, selain menu Dropdown pada halaman utama terdapat menu utama yaitu Berita Terbaru, Pengumuman dan Agenda. Menu utama ini dikoneksikan dengan database dengan menggunkan script:

Sript PHP Berita Terbaru adalah :

$<? p h p$

$\$ q u e r y=$ "SELECT id, judul, tanggal, head, pengirim

FROM berita ORDER BY id DESC LIMIT 0,5";

$\$ s q \mathrm{l}=$ mysqI_query (\$query);

while (\$hasil $=$ mysqI_fetch_array $(\$ s q l))\{$

\$id = \$hasil['id'];

\$judul = \$hasil['judul'];

\$head = \$hasil['head'];

\$tanggal = \$hasil['tanggal'];

\$pengirim = \$hasil['pengirim'];

echo "<a href='berita.php?id=\$id'><font size='5'> \$judul $</$ font $\rangle</ a\rangle<$ br $>$ Oleh

\$pengirim pada tanggal \$tanggal

$<b r><b r>$ \$head... <a href='berita.php?id=\$id'>Baca Selengkapnya $</ a><b r>" ;\}$

?>

\begin{tabular}{|c|c|c|}
\hline & \# Nama & Jenis \\
\hline$\square$ & $1 \underline{\text { id }}$ & $\operatorname{int}(6)$ \\
\hline$\square$ & 2 tanggal & datetime \\
\hline$\square$ & 3 judul & $\operatorname{varchar}(50)$ \\
\hline$\square$ & 4 head & varchar $(250)$ \\
\hline$\square$ & 5 isi & text \\
\hline$\square$ & 6 pengirim & $\operatorname{varchar}(30)$ \\
\hline
\end{tabular}

Gambar 4.2. Database Berita

\section{Scrip PHP Pengumuman :}

$<? p h p$

\$query = "SELECT id, judul, tanggal

FROM pengumuman ORDER BY id DESC LIMIT 0,5";

$\$ s q \mathrm{I}=$ mysqI_query (\$query);

while (\$hasil $=$ mysqI_fetch_array $(\$ s q l))\{$ 
\$id = \$hasil['id'];

\$judul = \$hasil['judul'];

echo "<a href='pengumuman.php? id=\$id's $\langle b\rangle$ \$judul $\langle/ b\rangle\langle/ a\rangle\langle b r\rangle$ ", ? ?>

\begin{tabular}{|c|c|c|}
\hline & \# Nama & Jenis \\
\hline$\square$ & $1 \underline{\text { id }}$ & $\operatorname{int}(6)$ \\
\hline$\square$ & 2 tanggal & datetime \\
\hline$\square$ & 3 judul & $\operatorname{varchar}(50)$ \\
\hline$\square$ & 4 isi & text \\
\hline$\square$ & 5 pengirim & $\operatorname{varchar}(30)$ \\
\hline
\end{tabular}

Gambar 4.3. Database Pengumuman

\section{Scrip PHP Agenda:}

$<$ ?php

\$query = "SELECT id, judul, tanggal

FROM agenda ORDER BY id DESC LIMIT 0,5";

$\$ s q I=$ mysqI_query (\$query);

while (\$hasil $=$ mysql_fetch_array $(\$ s q l))\{$

\$id = \$hasil['id'];

\$judul = \$hasil['judul'];

echo "<a href='agenda.php? id=\$id'><b> \$judul $\langle/ b\rangle\langle/ a\rangle\langle b r\rangle$ ";

\}? ?>

\begin{tabular}{|c|c|c|}
\hline & \# Nama & Jenis \\
\hline$\square$ & $1 \underline{\text { id }}$ & $\operatorname{int}(6)$ \\
\hline$\square$ & 2 tanggal & date \\
\hline$\square$ & 3 judul & $\operatorname{varchar}(50)$ \\
\hline$\square$ & 4 isi & text \\
\hline$\theta$ & 5 pengirim & $\operatorname{varchar}(50)$ \\
\hline
\end{tabular}

\section{Gambar 4.4 Database Agenda}

Sistem informasi sekolah setelah dikoneksikan dengan beberapa database di atas, maka hasilnya adalah seperti pada gambar 4.5 di bawah ini.

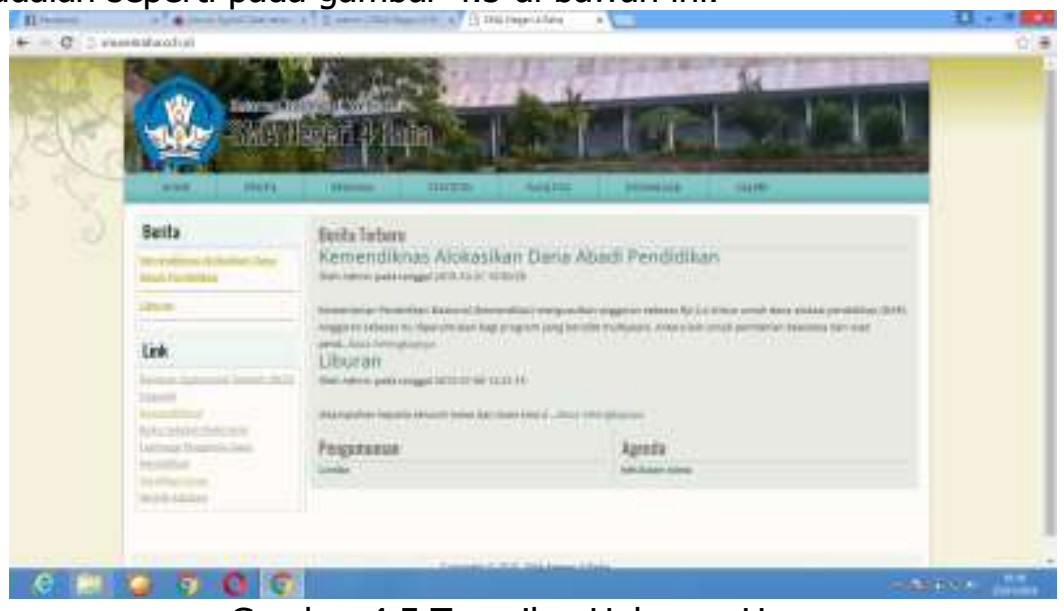

Gambar 4.5 Tampilan Halaman Home 
b. Halaman Profil

Menu Profil berisi tentang Profil Sekolah, serta Visi dan Misi SMA Negeri 4 Raha. Berikut ini Script Program Halaman Profil yang dikoneksikan dengan Database Profil.

\section{Script Menu Profil .}

$<? p h p$

\$query = "SELECT id, visimisi

FROM profil ORDER BY id";

$\$ s q \mathrm{I}=$ mysqI_query (\$query);

while (\$hasil $=$ mysql_fetch_array $(\$ s q I))\{$

\$id = \$hasil['id'];

\$visimisi = \$hasil['visimisi'];

echo "\$visimisi";

\}

?>

\section{Database Profil}

\begin{tabular}{|c|c|c|}
\hline & \# Nama & Jenis \\
\hline ᄃ & $1 \underline{\text { id }}$ & $\operatorname{int}(3)$ \\
\hline & 2 sejarah & varchar $(1000$ \\
\hline & 3 visin & , \\
\hline
\end{tabular}

Gambar 4.5. Database Profil

Script di atas setelah dikoneksikan dengan database profil, maka akan tampil seperti Gambar 4.6. dan Gambar 4.7.

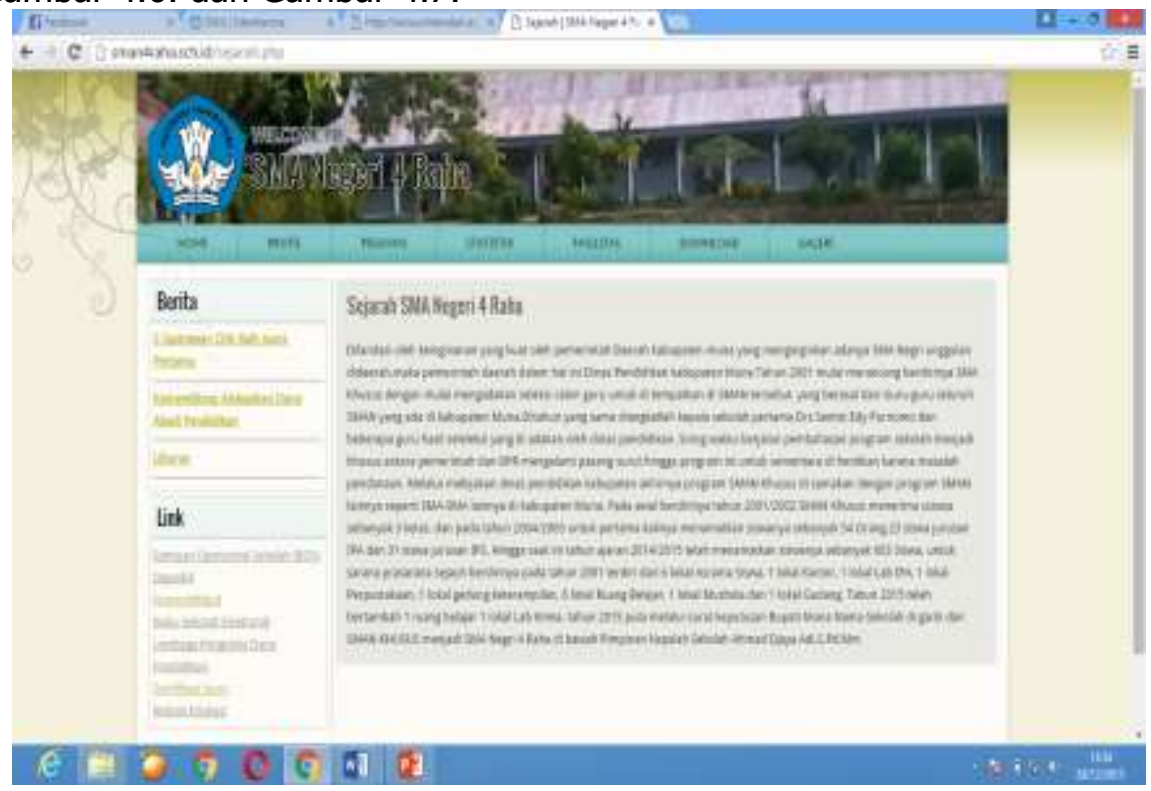

Gambar 4.6. Tampilan Sejarah SMA Negeri 4 Raha 


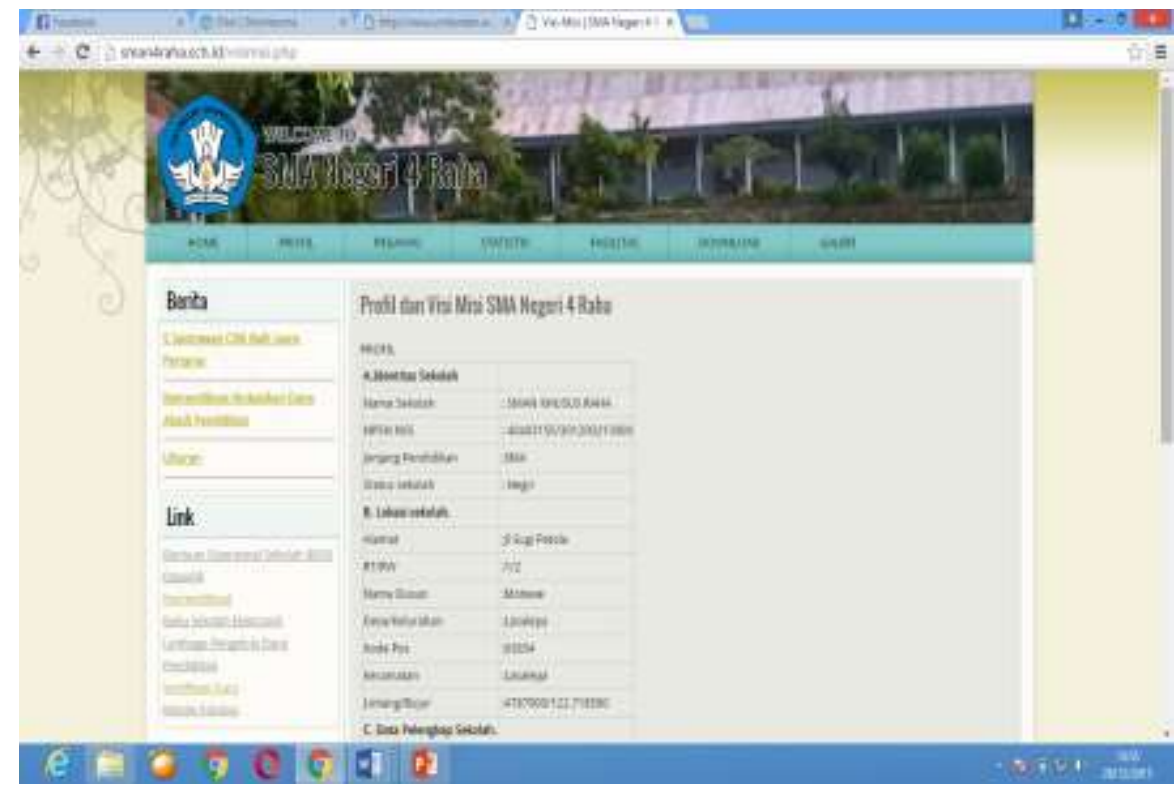

Gambar 4.7. Tampilan Profil dan Visi Misi SMA Negeri 4 Raha

c. Halaman Pegawai

Halaman pegawai Sistem Informasi Sekolah SMA Negeri 4 Raha terdapat menu dropdown, Menu ini setelah kursor mouse ditempatkan pada menu pegawai, maka akan tampil menu kependidikan dan menu tenaga kependidikan. Berikut ini sript menu pegawai :

\section{Script Tenaga Pendidik :}

$<? p h p$

\$query = "SELECT id, nama

FROM pegawai WHERE jabatan='Tenaga Pendidik' or jabatan $={ }^{\prime}$ Kepala Sekolah' ORDER BY pangkat";

$\$ s q l=$ mysqI_query (\$query);

while (\$hasil $=$ mysqI_fetch_array (\$sql)) \{

\$id = \$hasil['id'];

\$nama = \$hasil['nama'];

echo "\$nama<hr>";

\}

?>

Script di atas adalah script untuk menampilkan nama pegawai yang diambil dalam database pegawai..

\section{$<? p h p$}

\$query = "SELECT id, pangkat

FROM pegawai WHERE jabatan='Tenaga Pendidik' or jabatan='Kepala Sekolah' ORDER

BY pangkat";

$\$ s q l=$ mysqI_query (\$query);

while (\$hasil $=$ mysqI_fetch_array (\$sql)) \{

\$id = \$hasil['id'];

\$pangkat = \$hasil['pangkat'];

echo "<center>\$pangkat</center><hr>";

\}

?>

Script di atas adalah script untuk menampilkan pangkat dan golongan pegawai yang diambil dalam database pegawai.. 
\$query = "SELECT id, jabatan

FROM pegawai WHERE jabatan='Tenaga Pendidik' or jabatan='Kepala Sekolah' ORDER

BY pangkat";

$\$ s q I=$ mysql_query (\$query);

while (\$hasil $=$ mysql_fetch_array $(\$ s q I))\{$

\$id = \$hasil['id'];

\$jabatan = \$hasil['jabatan'];

echo "<center>\$jabatan</center $><h r>$ ";

\}

?>

Script di atas adalah script untuk menampilkan jabatan pegawai yang diambil dalam database pegawai..

$<? p h p$

$\$ q u e r y=$ "SELECT id, status

FROM pegawai WHERE jabatan='Tenaga Pendidik' or jabatan='Kepala Sekolah' ORDER

BY pangkat";

$\$ s q I=$ mysqI_query (\$query);

while (\$hasil $=$ mysqI_fetch_array $(\$ s q l))\{$

\$id = \$hasil['id'];

\$status = \$hasil['status'];

echo "<center $>$ \$status $</$ center $><h r>$ ";

\}

?>

Script di atas adalah script untuk menampilkan status pegawai yang diambil dalam database pegawai.

\section{Database Pegawai}

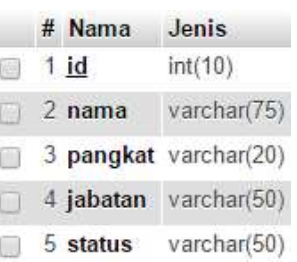

Gambar 4.8. Database Pegawai

Script di atas setelah dikoneksikan dengan database, maka akan tampil seperti gambar 4.9 dan Gambar 4.10.

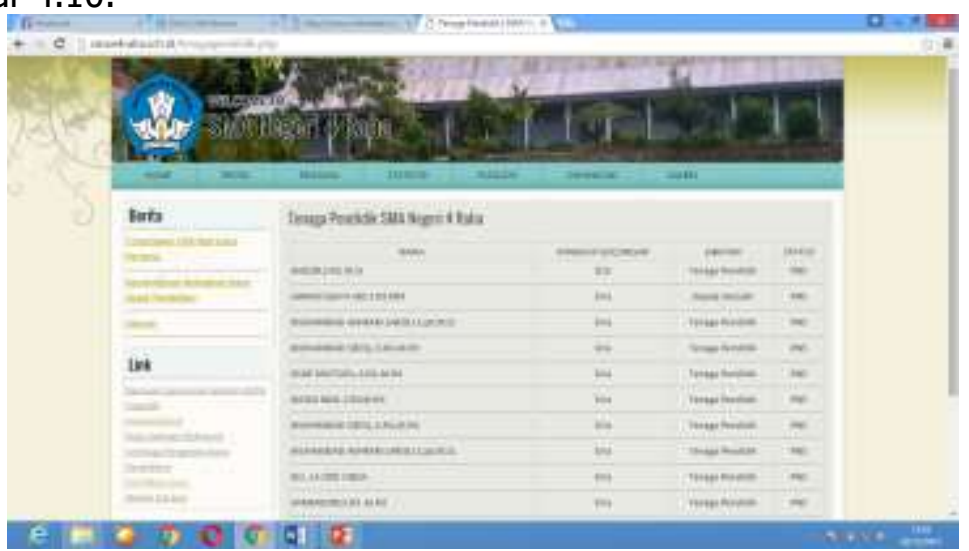

Gambar 4.9. Tampilan Halaman Tenaga Pendidik SMA Negeri 4 Raha 


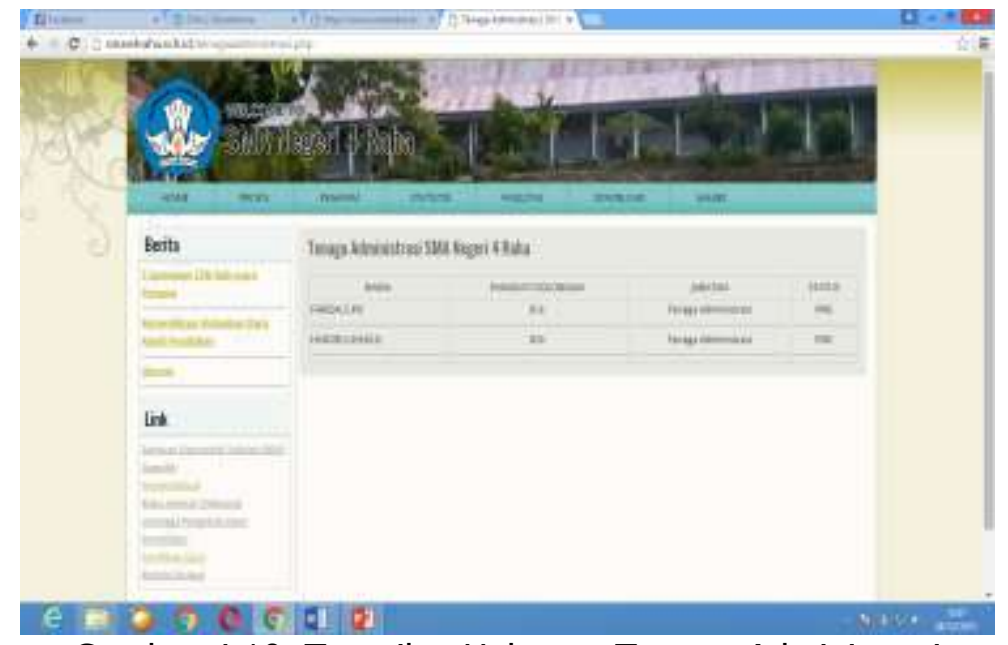

Gambar 4.10. Tampilan Halaman Tenaga Administrasi SMA Negeri 4 Raha

d. Halaman Statistik

Halaman statistik merupakan halaman yang menampilkan halaman siswa dan alumni. Berikut ini Script halaman siswa dan halaman alumni.

\section{Script Halaman Siswa}

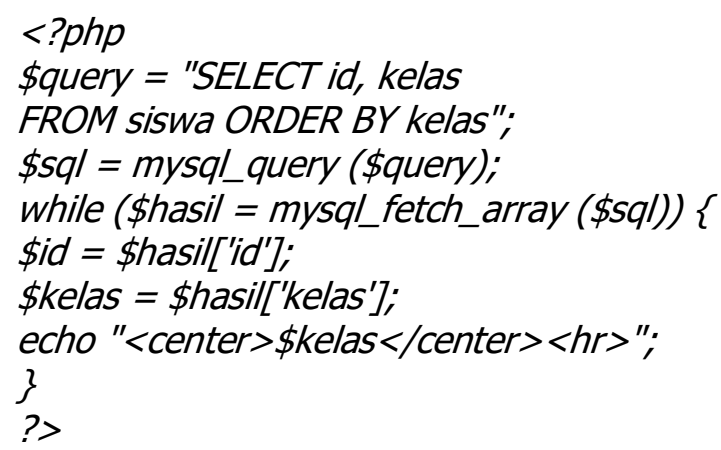

Script di atas adalah script untuk menampilkan jumlah siswa berdasarkan kelas siswa yang diambil dalam database siswa.

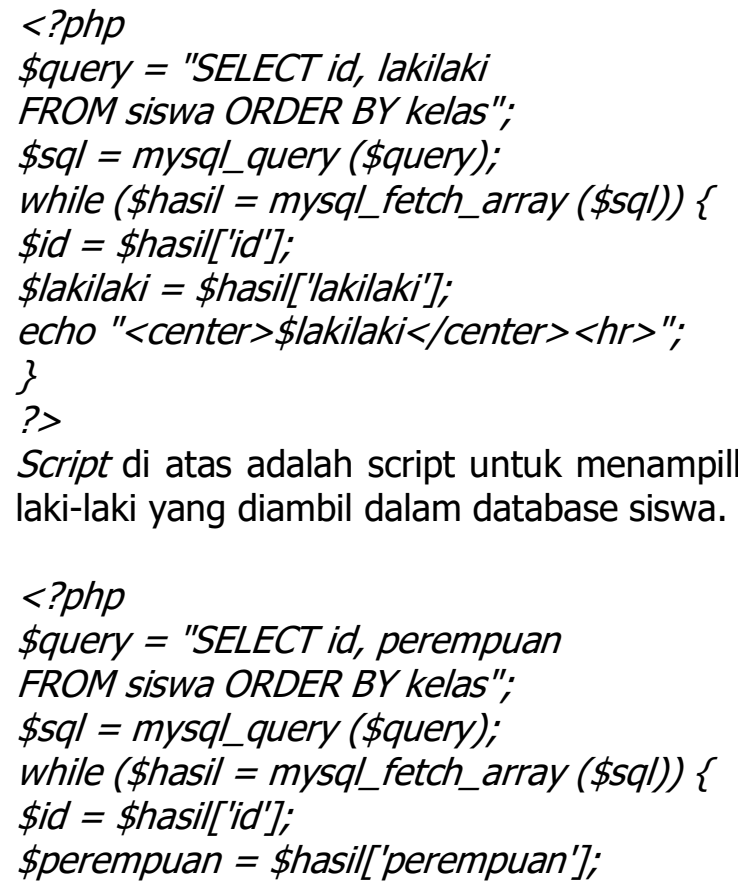
laki-laki yang diambil dalam database siswa.

Script di atas adalah script untuk menampilkan jumlah siswa berdasarkan jenis kelamin 
echo "<center>\$perempuan</center><hr>";

\}

?>

Script di atas adalah script untuk menampilkan jumlah siswa berdasarkan jenis kelamin perempuan yang diambil dalam database siswa.

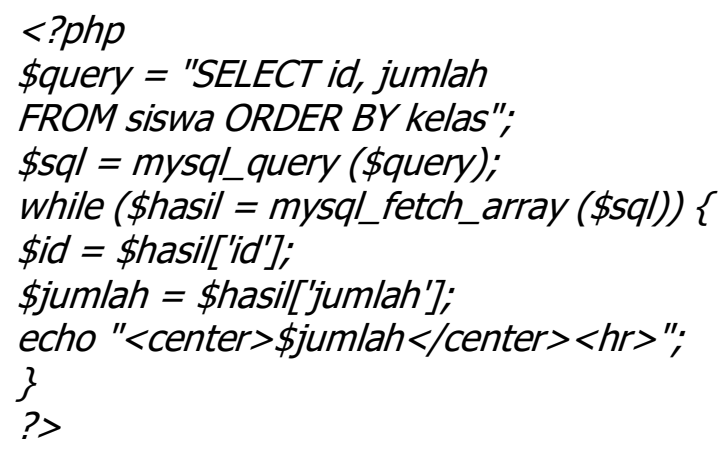

Script di atas adalah script untuk menampilkan total jumlah siswa berdasarkan jenis kelamin laki-laki dan perempuan yang diambil dalam database siswa.

\section{Database Siswa}

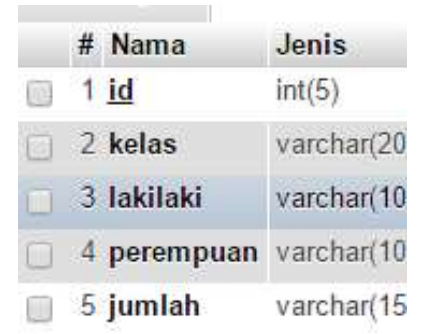

Gambar 4.11. Database Siswa

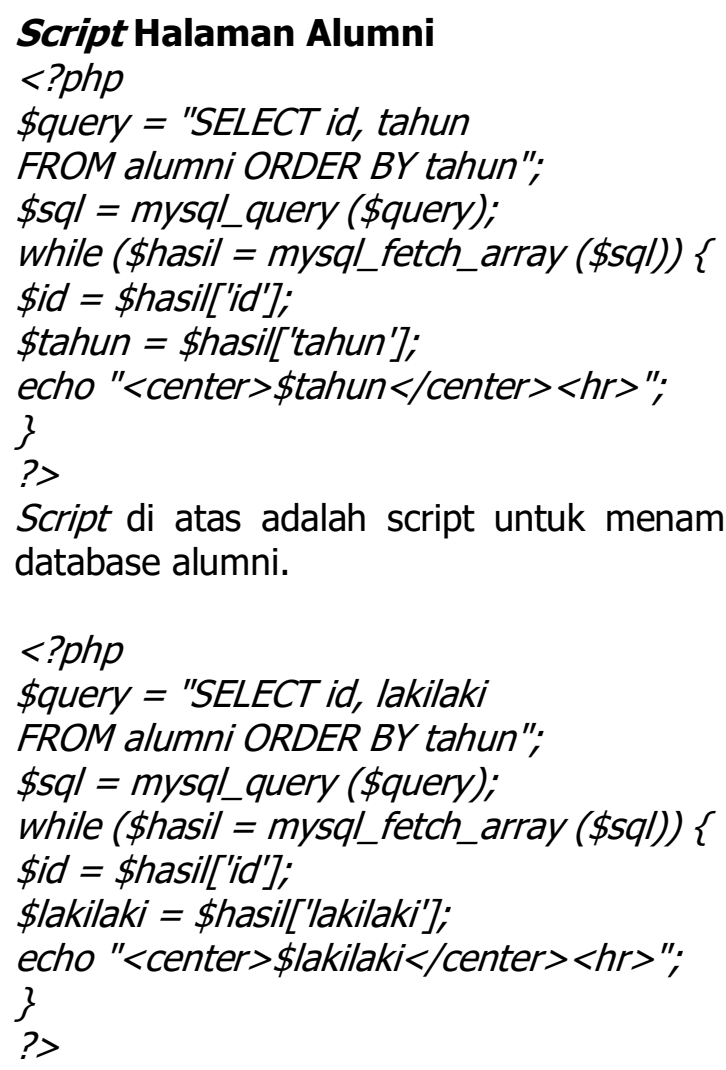


Script di atas adalah script untuk menampilkan jumlah siswa berdasarkan jenis kelamin laki-laki yang diambil dalam database alumni

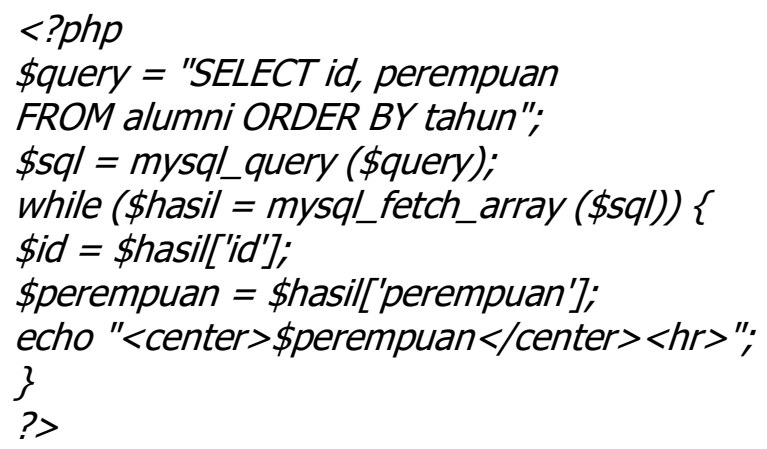

Script di atas adalah script untuk menampilkan jumlah siswa berdasarkan jenis kelamin perempuan yang diambil dalam database alumni.

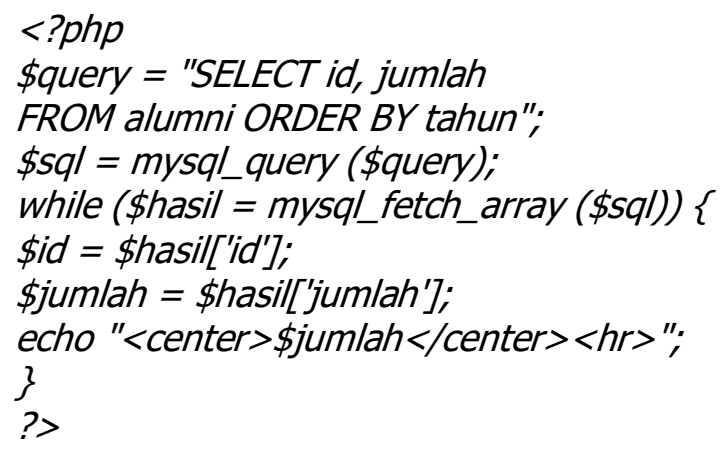

Script di atas adalah script untuk menampilkan jumlah total alumni laki-laki dan perempuan yang diambil dalam database alumni.

\section{Database Alumni}

\begin{tabular}{|c|c|c|}
\hline & \# Nama & Jenis \\
\hline 口 & $1 \underline{\text { id }}$ & $\operatorname{int}(5)$ \\
\hline Q & 2 tahun & varchar(10) \\
\hline D & 3 lakilaki & varchar(10) \\
\hline$\square$ & 4 perempuan & varchar(10) \\
\hline 6 & 5 jumlah & varchar(15) \\
\hline
\end{tabular}

Gambar 4.12. Database Alumni

Hasil dari kedua script di atas dapat dilihat pada gambar 4.13. dan Gambar 4.14.

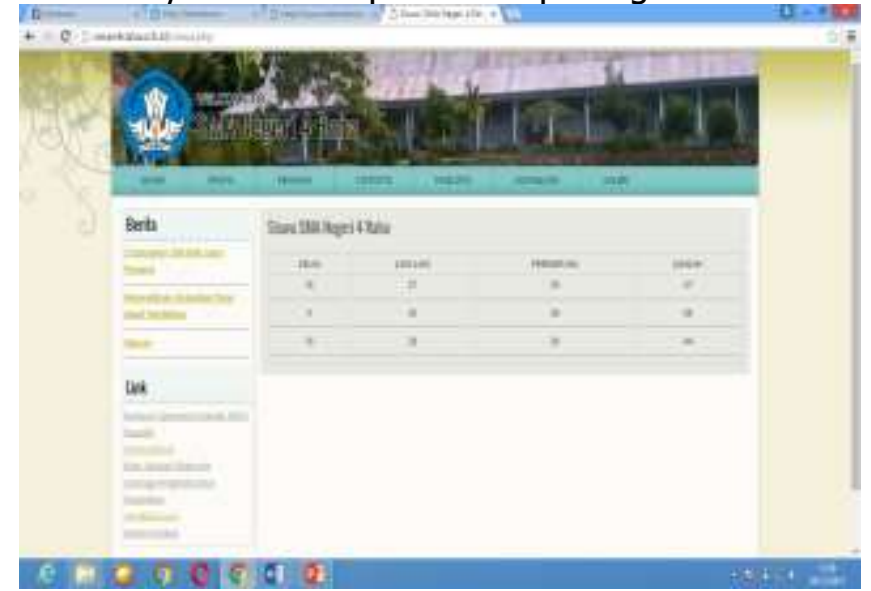

Gambar 4.13. Tampilan Halaman Statistik Siswa SMA Negeri 4 Raha 


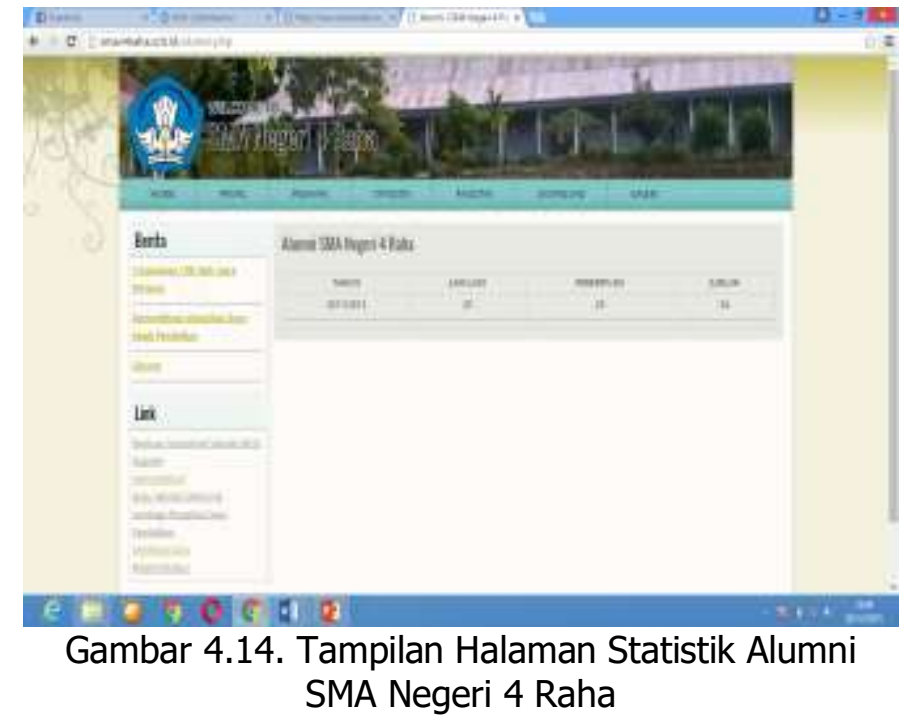

e. Halaman Fasilitas

Halaman Fasilits merupakan halaman yang menampilkan fasilitas yang ada di SMA Negeri 4 Raha. Berikut Script Menu Fasilitas:

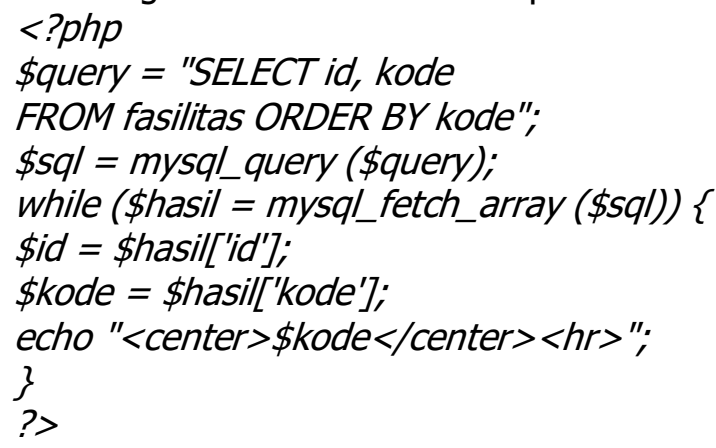


\$jumlah = \$hasil['jumlah'];

echo "<center>\$jumlah unit</center ><hr>";

\}

$>$

Script di atas adalah script untuk menampilkan jumlah barang yang diambil dalam database.

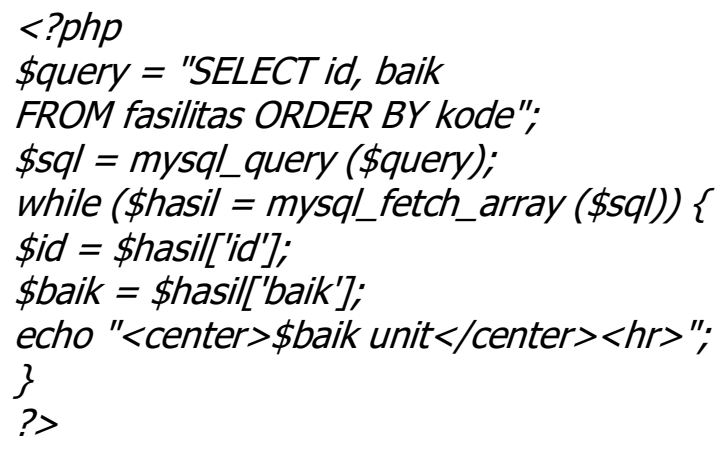

Script di atas adalah script untuk menampilkan kondisi barang baik yang diambil dalam database.

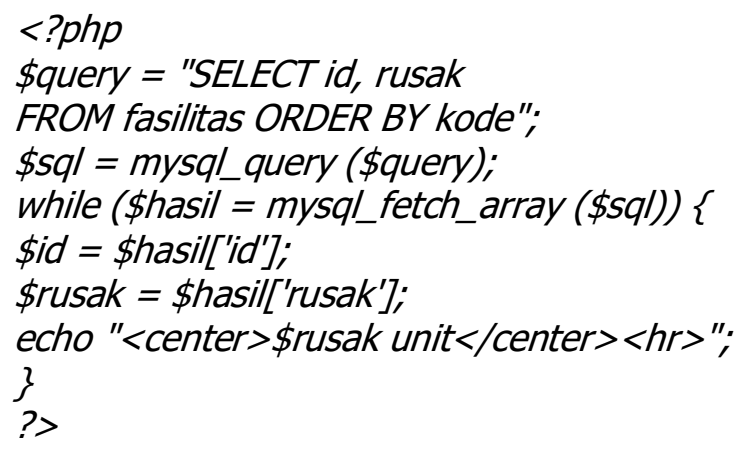

Script di atas adalah script untuk menampilkan kondisi barang rusak yang diambil dalam database.

\section{Database Fasilitas}

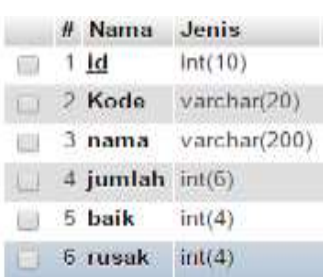

Gambar 4.15. Database Fasilita

Hasil dari script Fasilitas di atas dapat dilihat pada gambar 4.16 di bawah ini.

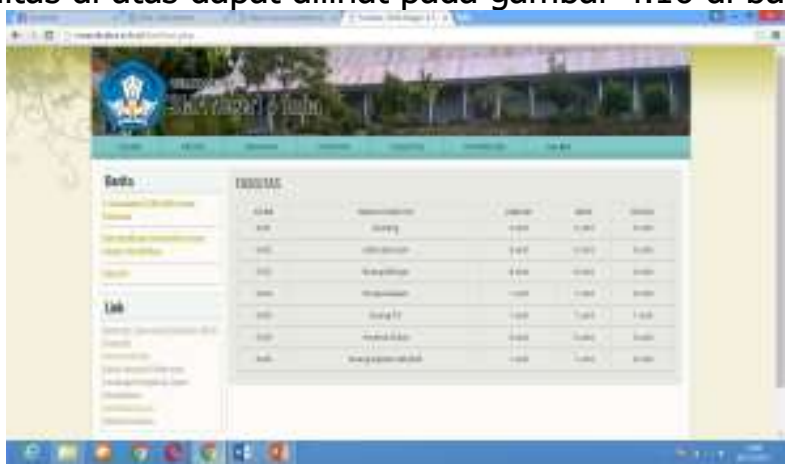

Gambar 4.16. Tampilan Halaman Fasilitas SMA Negeri 4 Raha 
f. Halaman Download

Halaman download merupakan halaman tempat menyimpan file-file yang dapat didownload oleh pengunjung seperti RPP, Silabus, Materi Ajar, dan lain-lain.

Script Halaman Download adalah sebagai berikut :

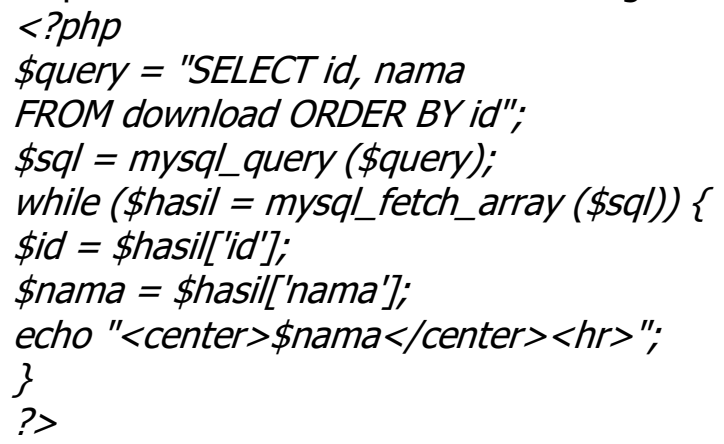

Script di atas adalah script untuk menampilkan nama file yang diambil dalam database.

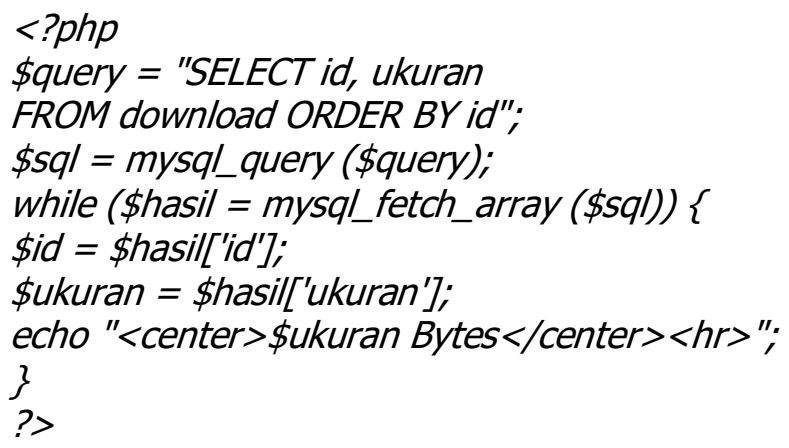

Script di atas adalah script untuk menampilkan ukuran file yang diambil dalam database.

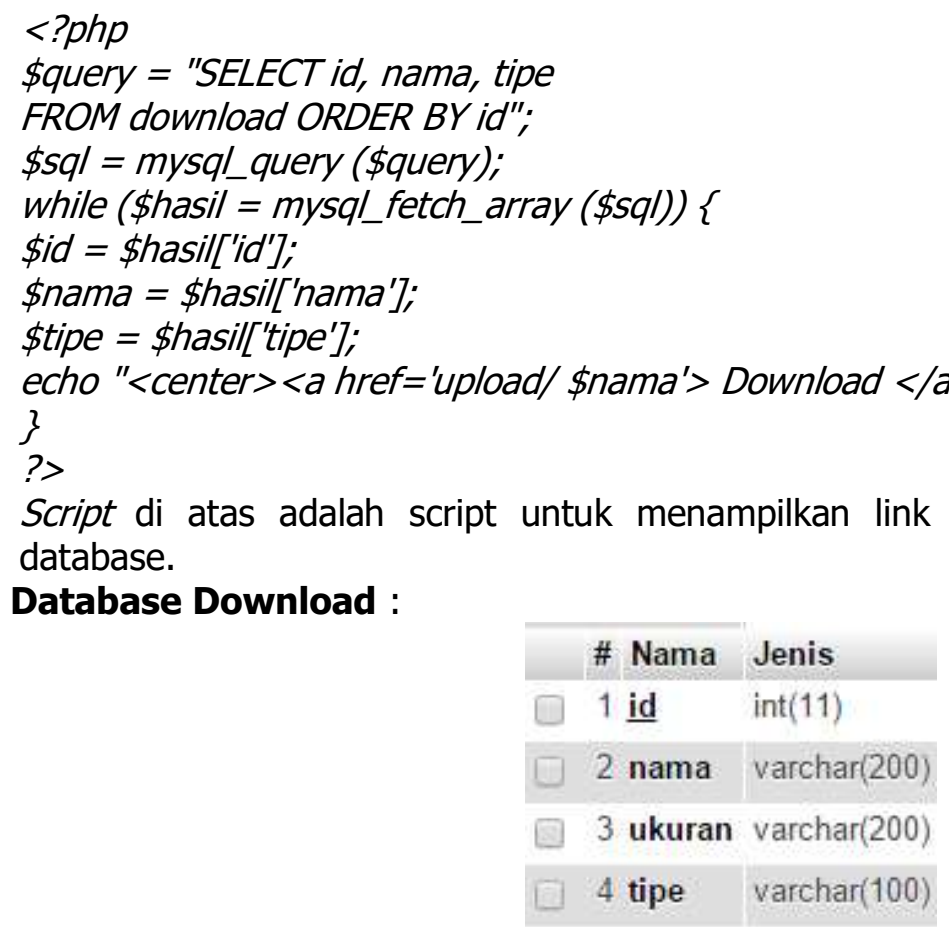

\begin{tabular}{|c|c|c|}
\hline & \# Nama & Jenis \\
\hline$\square$ & $1 \underline{\mathbf{i d}}$ & int(11) \\
\hline$\square$ & 2 nama & varchar(200) \\
\hline Q & 3 ukuran & varchar(200) \\
\hline 口 & 4 tipe & $\operatorname{varchar}(100)$ \\
\hline
\end{tabular}

Gambar 4.17. Database Download

Hasil dari Script di atas adalah seperti ditampilkan pada gambar 4. 18. 
g. Halaman Galeri

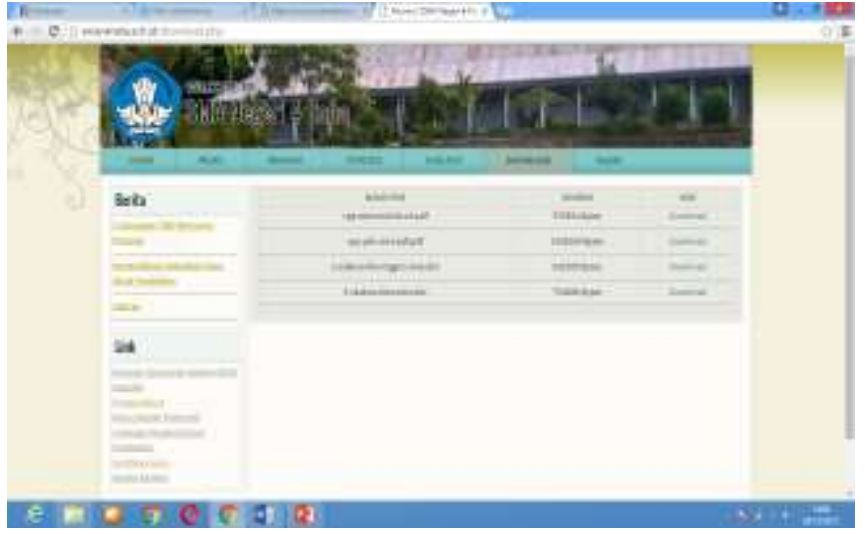

Gambar 4.18. Tampilan Halaman Download

Halaman galeri merupakan halaman tempat menyimpan dokumentasi kegiatan yang diadakan oleh sekolah. Script Halaman Galeri adalah sebagai berikut :

$<? p h p$

\$query = "SELECT id, nama, judul

FROM galeri ORDER BY id";

$\$$ sql = mysql_query (\$query);

while ( $\$$ hasil $=$ mysql_fetch_array $(\$ s q l))\{$

\$id = \$hasil['id'];

\$nama = \$hasil['nama'];

\$judul = \$hasil['judul'];

echo "<img src='galeri/\$judul' width='30\%' align='left'>";

\}? ?>

Script diatas adalah script yang menampilkan gambar galeri.

\section{Database Galeri}

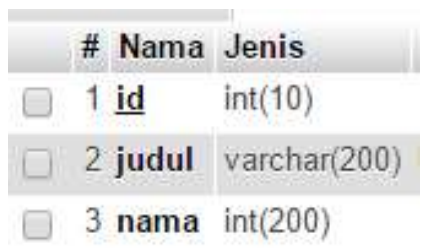

Gambar 4.19. Database Galeri

Hasil dari Script di atas adalah seperti ditunjukkan pada gambar 4.20. dibawah ini.

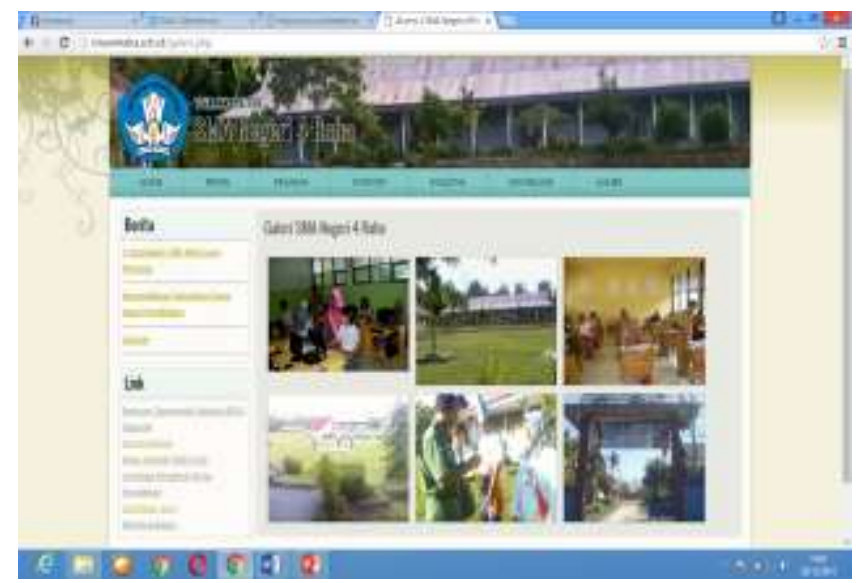

Gambar 4.20. Tampilan Halaman Galeri 


\section{Hasil Pengujian Program Oleh User (Siswa), Ahli SIM.}

a. Hasil Pengujian

Tahap pengujian Sistem Informasi Sekolah berbasis Web dilakukan sesuai dengan rancangan desain Sistem Informasi Sekolah yang dilakukan sesuai yang dijelaskan pada Bab III di atas. Pengujian dilakukan dengan validasi Oleh Ahli SIM yang diambil dari berlatar belakang S.KOM, dan Pihak Sekolah, Selain itu, dilakukan uji coba terhadap user yang dapat mengakses sistem informasi sekolah tersebut.

1. Hasil Uji Kelayakan oleh Ahli SIM

Sistem Informasi sekolah yang telah didesain dilakukan uji coba untuk melihat kelayakan. Uji coba tersebut dilakukan oleh ahli SIM. Dalam uji coba ini dinilai dari aspek Kecepatan akses website yang terdiri dari 3 (tiga) butir peryataan dan dari Aspek Usability yang terdiri dari 4 (empat) butir peryataan. ini:

Data dari hasil uji kelayakan Ahli SIM dapat dilihat pada table 4.1 di bawah

Tabel 4.1. Data Hasil Uji Kelayakan SIM

\begin{tabular}{|l|l|c|c|c|c|}
\hline No. & Aspek Penilaian & $\begin{array}{c}\text { Skor } \\
\text { Observasi }\end{array}$ & $\begin{array}{c}\text { Skor } \\
\text { Yang } \\
\text { diharapk } \\
\text { an }\end{array}$ & $\begin{array}{c}\text { Kelaya } \\
\text { kan } \\
\text { (\%) }\end{array}$ & \multicolumn{1}{|c|}{ Ket. } \\
\hline 1. & $\begin{array}{l}\text { Kecapatan Akses } \\
\text { Website }\end{array}$ & 28 & 36 & 77.78 & $\begin{array}{c}\text { Sangat } \\
\text { Layak }\end{array}$ \\
\hline 2. & Usability & 39 & 48 & 81.25 & $\begin{array}{c}\text { Sangat } \\
\text { Layak }\end{array}$ \\
\hline & Jumlah & 67 & 84 & 79.76 & $\begin{array}{c}\text { Sangat } \\
\text { Layak }\end{array}$ \\
\hline
\end{tabular}

Sumber : Data Olahan 2015

gambar 4.21.

Data tersebut diatas bila digambarkan dalam grafik dapat dilihat pada

Dari Tabel 4.1. di atas dapat dilihat bahwa Sistem Informasi Sekolah SMA Negeri 4 Raha dapat dikategorikan Sangat Layak dengan persentase Kelayakan sebesar $79,76 \%$.

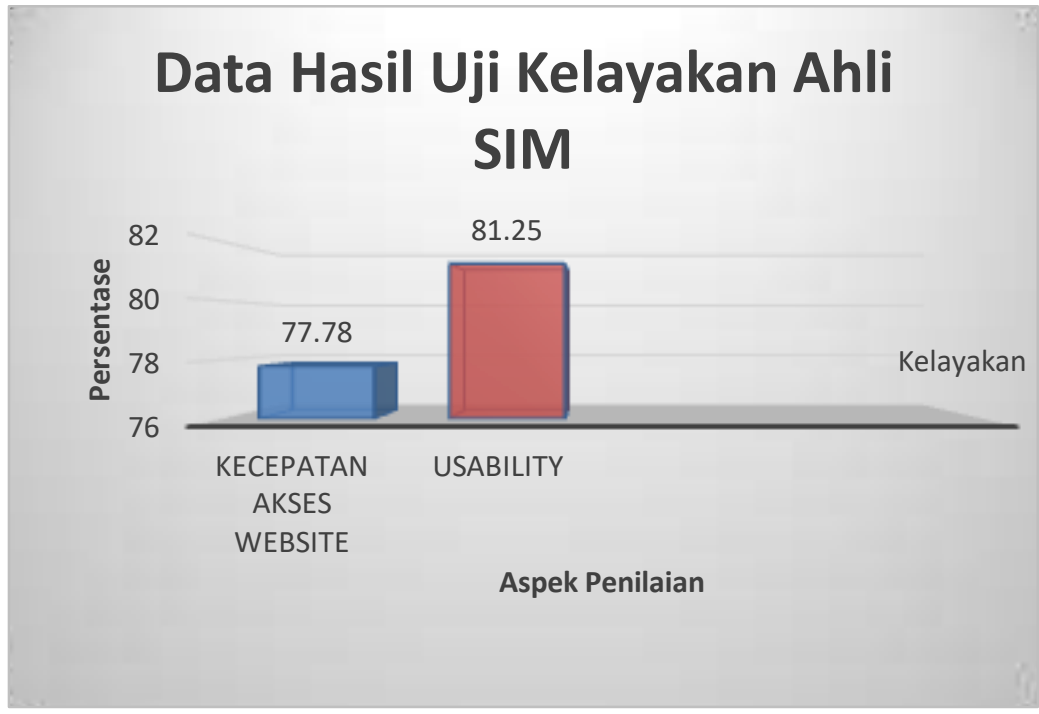

Gambar 4.21 Diagram Hasil Uji Kelayakan Ahli SIM

2. Hasil Uji Kelayakan oleh Pihak Sekolah

Setelah melakukan uji kelayakan oleh ahli SIM, maka dilakukukan Uji Kelayakan terhadap pihak sekolah sebagai pengguna. Penilaian dalam uji kelayakan ini dinilai dari 2 (dua) Aspek yaitu Aspek Kelayakan konten yang terdiri dari 8 (delapan) butir peryataan, dan aspek Kelayakan Desain yang terdiri dari 11 (sebelas) 
butir peryataan. Data hasil uji kelayakan terhadap pihak sekolah dapat dilihat pada Tabel 4.2 di bawah ini.

Tabel Uji Kelayakan Oleh Pihak Sekolah

\begin{tabular}{|c|c|c|c|c|c|}
\hline No. & $\begin{array}{c}\text { Aspek } \\
\text { Penilaian }\end{array}$ & $\begin{array}{c}\text { Skor } \\
\text { Observasi }\end{array}$ & $\begin{array}{c}\text { Skor } \\
\text { Yang } \\
\text { diharapk } \\
\text { an }\end{array}$ & $\begin{array}{c}\text { Kelaya } \\
\text { kan } \\
(\%)\end{array}$ & Ket. \\
\hline 1. & $\begin{array}{l}\text { Kelayakan } \\
\text { Konten }\end{array}$ & 133 & 192 & 69.27 & $\begin{array}{c}\text { Sangat } \\
\text { Layak }\end{array}$ \\
\hline 2. & $\begin{array}{l}\text { Kelayakan } \\
\text { Desain }\end{array}$ & 192 & 325 & 59.08 & $\begin{array}{c}\text { Sangat } \\
\text { Layak }\end{array}$ \\
\hline & Jumlah & 325 & 517 & 62.86 & $\begin{array}{c}\text { Sangat } \\
\text { Layak }\end{array}$ \\
\hline
\end{tabular}

Sumber : Data Olahan 2015

Data tersebut diatas bila digambarkan dalam grafik dapat dilihat pada gambar 4.22 di bawah ini:

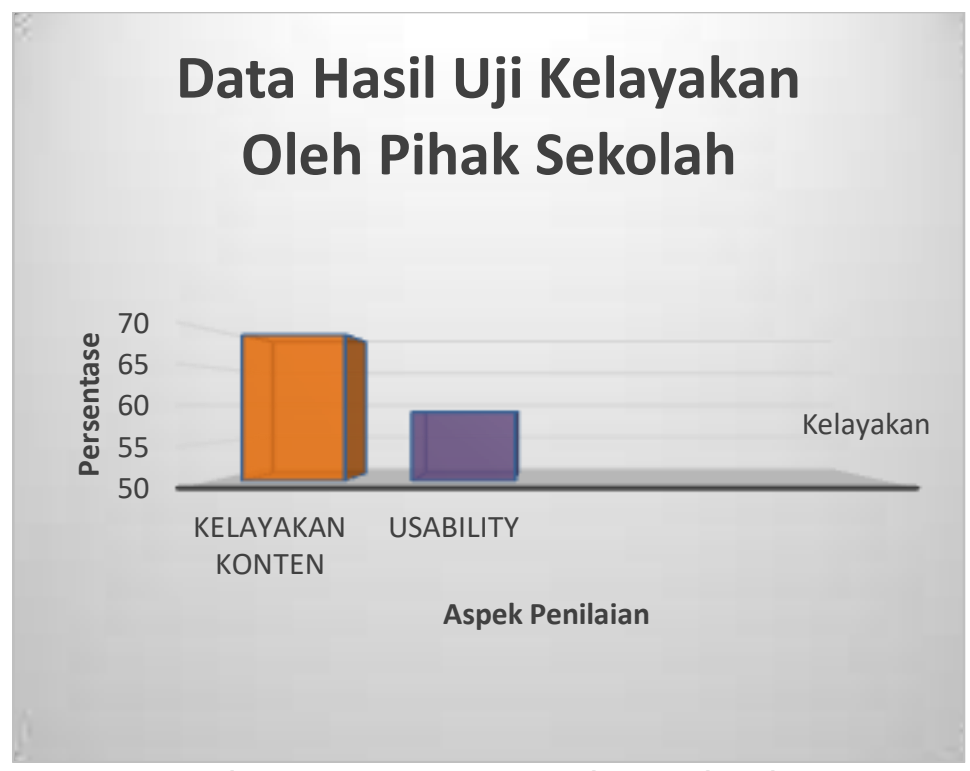

Gambar 4.22 Diagram Hasil Uji Kelayakan Oleh Pihak Sekolah

Dari Tabel 4.2. di atas dapat dilihat bahwa Sistem Informasi Sekolah SMA Negeri 4 Raha dapat dikategorikan Layak dengan persentase Kelayakan sebesar $62,86 \%$.

3. Hasil Uji Kelayakan oleh User

Setelah dilakukan uji kelayakan oleh ahli SIM dan pihak sekolah maka dilakukan uji kelayakan terhadap pengguna sistem informasi sekolah berbasis web (Siswa). Dalam uji kelayakan ini dinilai dari aspek kecepatan akses website yang terdiri dari 8 (delapan) item peryataan. Data hasil uji kelayakan terhadap User dapat dilihat pada table 4.3.

Tabel 4.3. Data Hasil Uji Kelayakan Oleh User (Siswa)

\begin{tabular}{|c|c|c|c|c|c|}
\hline No. & Aspek Penilaian & $\begin{array}{c}\text { Skor } \\
\text { Observa } \\
\text { si }\end{array}$ & $\begin{array}{c}\text { Skor } \\
\text { Yang } \\
\text { diharapk } \\
\text { an }\end{array}$ & $\begin{array}{c}\text { Kelayakan } \\
\text { (\%) }\end{array}$ & Ket. \\
\hline
\end{tabular}




\begin{tabular}{|c|c|c|c|c|c|}
\hline 1. & $\begin{array}{l}\text { Kecapatan } \\
\text { Akses Website }\end{array}$ & 307 & 320 & 95,94 & $\begin{array}{c}\text { Sangat } \\
\text { Layak }\end{array}$ \\
\hline Jumlah & 307 & 320 & 95,94 & $\begin{array}{c}\text { Sangat } \\
\text { Layak }\end{array}$ \\
\hline
\end{tabular}

Sumber : Data Olahan 2015

Data tersebut diatas bila digambarkan dalam grafik dapat dilihat pada gambar 4.23 di bawah ini:

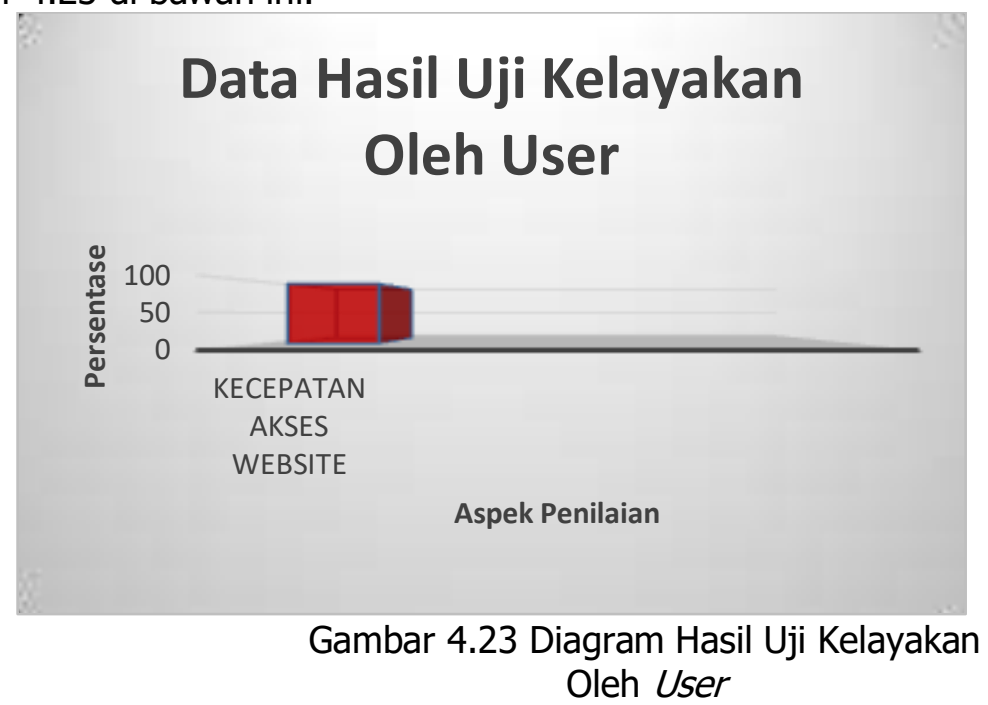

Dari Tabel 4.3. di atas dapat dilihat bahwa Sistem Informasi Sekolah SMA Negeri 4 Raha dapat dikategorikan Sangat Layak dengan persentase Kelayakan sebesar 95,94 \%.

\section{SIMPULAN DAN SARAN Kesimpulan}

Berdasarkan hasil penelitian dan pembahasan maka dapat ditarik kesimpulan bahwa : Hasil dari penelitian ini menghasilkan suatu Sistem Informasi Sekolah Berbasis Web. Sistem informasi sekolah berbasis web yang telah didesain di SMA Negeri 4 Raha Layak diimplementasikan sebagai media yang dapat digunakan untuk menyebarluaskan informasi, khususnya informasi SMA Negeri 4 Raha. Hasil persentase uji kelayakan oleh ahli SIM dengan melibatkan 3 orang responden menyatakan sangat layak dengan persentase sebesar $79,76 \%$, Uji Kelayakan oleh pihak sekolah dengan melibatkan 5 orang responden menyatakan layak dengan persentase sebesar 62,86\%, dan Hasil uji kelayakan oleh User dengan melibatkan 10 orang responden menyatakan sangat layak dengan persentase sebesar 95,94 \%, Sehingga persentase secara keseluruhan sebesar 75, $90 \%$. Dan diinterprestasikan layak diimplementasikan sebagai media informasi di SMA Negeri 4 Raha

\section{Saran}

Bagi Peneliti selanjutnya yang ingin mengembangkan Sistem informasi ini disarankan

a) Pada tampilan awal website perlu ditambahkan beberapa fitur agar lebih menarik, seperti slide show dokumentasi kegiatan atau prestasi sekolah.

b) Pada statistik alumni agar titampilkan nama dan identitas alumni dan ditambahkan form alumni, keguanaanya agar alumni yang belum terdaftar dapat melakukan registrasi sendiri.

c) Pengembangan system informasi sekolah ini agar ditambahkan dengan SIM Akademik, SIM Kepegawaian, SIM Alumni dan SIM Kesiswaan Sehingga akan menjadi sebuah Sistem Informasi yang kompleks. 


\section{DAFTAR PUSTAKA}

Al Fatta, Hanif. 2007, Analisis dan Perancangan Sistem Informasi untuk keunggulan bersaing Perusahaan dan Organisasi Modern. CV Andi Offset, Yogyakarta.

Albahra Bin Lajamuddin. 2005, Analisis dan Sistem Informasi, Graha Ilmu, Yogyakarta.

Anonim, 2005. Sistem Informasi berbagai makalah tentang sistem informasi dari prespektif: manusia dan sistem informasi, Organisasi dan Sistem Informasi, Teknologi dan Sistem Informasi yang disampaikan dalam konferensi Nasional Sistem Informasi 2005 di Institut Teknologi Bandung, Informatika Bandung. Bandung

Arikunto, Suharsimi. 1996. Prosedur Penelitian Suatu Pendekatan Praktek. Jakarta: PT. Rineka Cipta.

Imansyah, Muhammad, 2003. PHP dan MySQL Untuk orang awam. Palembang Maxikom.

Iskandar, 2010. Metodologi Penelitian Pendidikan dan Sosial (Kuantitatif dan Kualitatif). Jakarta: Gaung Persada Press.

Jogiyanto. 2005, Analisis \& Desain Sistem Informasi: Pendekatan Terstruktur Teori dan Praktek Aplikasi Bisnis, Andi, Yogyakarta.

Kristanto, Andri, 2004, Jaringan Syaraf Tiruan (Konsep Dasar, Algoritma, dan Aplikasinya), Gava Media, Yogyakarta.

Madcoms, 2008, Teknik Mudah Membangun Website Dengan Html, Php Dan Mysql. CV Andi Offset, Yogyakarta.

Medinets, David. 2000. PHP3 Programming Browser-Based Application. McGraw-Hill. New York.

Sugiyono, 2010, Metode Penelitian Kuantitatif Kualitatif dan R\&D. Alfabeta, Bandung.

Sutabri. 2005. Analisa Sistem Informasi. Andi Publisher. Yogyakarta

Sutanta, Edhy, 2003. Sistem Informasi Manajemen. Yogyakarta:PT.Graha Ilmu. 